IZA DP No. 8088

The Great Compression of the French Wage Structure, 1969-2008

Gregory Verdugo

March 2014 


\title{
The Great Compression of the French Wage Structure, 1969-2008
}

\author{
Gregory Verdugo \\ Banque de France \\ and IZA
}

\section{Discussion Paper No. 8088 \\ March 2014}

\author{
IZA \\ P.O. Box 7240 \\ 53072 Bonn \\ Germany \\ Phone: +49-228-3894-0 \\ Fax: +49-228-3894-180 \\ E-mail: iza@iza.org
}

Any opinions expressed here are those of the author(s) and not those of IZA. Research published in this series may include views on policy, but the institute itself takes no institutional policy positions. The IZA research network is committed to the IZA Guiding Principles of Research Integrity.

The Institute for the Study of Labor (IZA) in Bonn is a local and virtual international research center and a place of communication between science, politics and business. IZA is an independent nonprofit organization supported by Deutsche Post Foundation. The center is associated with the University of Bonn and offers a stimulating research environment through its international network, workshops and conferences, data service, project support, research visits and doctoral program. IZA engages in (i) original and internationally competitive research in all fields of labor economics, (ii) development of policy concepts, and (iii) dissemination of research results and concepts to the interested public.

IZA Discussion Papers often represent preliminary work and are circulated to encourage discussion. Citation of such a paper should account for its provisional character. A revised version may be available directly from the author. 


\section{ABSTRACT \\ The Great Compression of the French Wage Structure, 1969-2008*}

Wage inequality decreased continuously in France from 1969 to 2008. In contrast to the US and the UK, this period was also characterised by a substantial increase in the educational attainment of the labour force. This paper investigates whether differences in the timing of educational expansion over the last forty years can explain the divergent evolution of upper tail wage inequality in France relative to other countries. Using a model with imperfect substitution between experience groups, the estimates suggest that the rapid increase in the supply of educated workers during the 1970s and 1990s produced a substantial decline in the skill premium within cohorts. As a result, between a third and half of the decline in wage inequality at the top of the distribution in France during this period is explained by the increase in the educational attainment of the labour force.

JEL Classification: J31

Keywords: $\quad$ wage inequality, France

Corresponding author:

Gregory Verdugo

Banque de France

31 rue Croix-des-petits-champs

75049 Paris Cedex 01

France

E-mail: gregory.verdugo@banque-france.fr

\footnotetext{
* I thank the Centre Maurice Halbwachs $(\mathrm{CMH})$ for having made the LFS-FQP data available. The author accessed the DADS-EDP data via the Centre d'Accès Sécurisé Distant (CASD), dedicated to the use of authorized researchers, following the approval of the Comite français du secret statistique. This research was partially supported by a French State grant ANR-10-EQPX-17 (Centre d'accès sécurisé aux données - CASD). I particularly thank Francis Kramarz and Alain Trannoy for their detailed comments on a previous draft. I also thank Hervé le Bihan, Guillaume Horny, two anonymous referees and seminar participants at the AMSE, Banque de France, Paris School of Economics and CEPR-IZA workshop for insightful comments. This paper does not necessarily reflect the views of the Banque de France.
} 


\section{Introduction}

A large body of literature documents the dramatic growth in earnings inequality that has occurred in many developed countries. A series of important papers by Autor et al. (2008) and Dustmann et al. (2009) argue that the increase in wage inequality in the US and Germany reflects a more rapid change in the demand for than in the supply of skills, particularly at the top of the wage distribution. ${ }^{1}$ In contrast, Card and DiNardo (2002) conclude that institutional changes, notably the fall in the real minimum wage in the US, provide a more consistent explanation of these widening inequalities.

A study of the French case could yield interesting evidence and improve our understanding of the factors underlying the evolution of the wage structure across developed countries. It can be argued, following Card et al. (1999), that similar negative shocks have affected the relative demand for less-skilled workers in France and the US. However, other important factors differ widely between the two countries. In particular, we highlight that the major differences include not only the evolution of the real minimum wage, which increased substantially in France during the period, but also differences in the timing of higher education expansion during the second half of the twentieth century. This educational expansion occurred only after the 1980s, much later than in the US where the educational attainment of the population stagnated during this period (Card and Lemieux, 2001; Goldin and Katz, 2008). To the best of our knowledge, the impact of differences in the timing of educational expansion on

\footnotetext{
${ }^{1}$ See also Goldin and Katz (2008) or Blau and Kahn (1996) for an earlier reference. For the UK, Goos and Manning (2007),Machin and Van Reenen (2007) and Gosling et al. (1994) highlight the increased polarization of the labor market since 1990, particularly at the top of the wage distribution.
} 
the wage structures of France and other countries has not been explored in detail in the recent literature. $^{2}$

In this paper, we document the relationship between changes in education levels and changes in the wage structure in France during the second half of the 20th century, focusing particularly on the 1969-2008 period, for which individual level data on wages are available. Our primary analysis focuses on men. ${ }^{3}$

Following a description of the data and the main characteristics of the massive French educational expansion in Section 1, we describe the evolution of the wage structure in Section 2. We find that although contemporary wage dispersion is low in France compared to other countries, this has not always been the case. Wage dispersion was actually higher in France than in the US during the 1960s, while the reverse has been true since the 1990s, a period in which the supply of skilled labour increased more rapidly in France. As a result, the evolution of the French wage structure in the second half of the 20th century is the mirror image of that in the US or the UK: a substantial increase in wage inequality initially occurred following the Second World War until the end of the 1960s, when the supply of skilled workers stagnated, followed by a substantial decline in inequality during the 1970s and after 1995, when education levels increased.

We demonstrate that these basic findings are robust to a variety of measurement issues, including differences in wage measures and changes in labour force composition due to secular or cyclical changes in employment probability across workers.

\footnotetext{
${ }^{2}$ A notable exception is Walker and Zhu (2008), who examine the impact of the expansion of higher education in the UK during the 1990s on the college premium. They find little reduction in the college premium during this period. In contrast, Carrasco et al. (2012) find that the compression of the wage structure in Spain during the 2000s is mostly explained by an increase in skilled-workers supply.

${ }^{3}$ The evolution of the wage structure is broadly similar for men and women in the recent period (see Verdugo et al. (2012) ). However, the large increase in female labor force participation suggests that the selection of women into the labor force changed considerably. Accounting for the selection effect of women entering the labor force on the wage structure is beyond the scope of this paper.
} 
In Section 3, we highlight that the decline in the skill premium accounts for the majority of the decline in wage inequality in recent decades. While the skill premium decreased substantially within narrowly defined demographic groups, residual inequality remained unchanged or even declined.

In Section 4, we use models based on CES production functions to identify the elasticity of the skill premium with respect to changes in supply. We find that a model à la Card and Lemieux (2001), which allows for imperfect substitution between experience groups, fits the evolution of between-group wage differences within cohorts well.

Overall, our results suggest that the observed "Great Compression" ${ }^{4}$ of wages in France is the result of two distinct mechanisms. For the lower part of the wage distribution, most evidence indicates that the minimum wage dramatically reduced lower-tail inequality. In contrast, a substantial share of the decrease in the skill premium and in upper-tail inequality appears to largely reflect increases in graduation rates. Our estimates suggest that the increases in the relative supply of education within experience groups explain between a third and half of the decrease in upper tail inequality and the skill premium within these groups over the 1969-2008 period.

\section{Related literature}

Influential papers published in the late 1990s, concluded that France did not experience skillbiased technological change during the 1980s and 1990s, arguing that the main source of wage inequality in France was not technological but institutional. ${ }^{5}$ However, the relative stability of the upper part of the distribution in recent years cannot be explained by institutional factors such

\footnotetext{
${ }^{4}$ This term is borrowed from Goldin and Margo (1992).

${ }^{5}$ See Goux and Maurin (2000) and Card et al. (1999). In contrast to findings for the US, Card et al. (1999) found no relationship between computer utilization across demographic groups at the end of the 1980s and subsequent wage changes in France. See also Charnoz et al. (2013) and Charnoz et al. (2011) for a recent descriptive analysis.
} 
as the minimum wage. We underline that, as shown for the US by Katz and Murphy (1992) or Card and Lemieux (2001), changes in the supply of education may also explain a substantial share of the trends in wage inequality in France. ${ }^{6}$

Compared to earlier studies, we also employ considerably more data that are now available. $^{7}$ The inclusion of the 1990 s and 2000 s is crucial because this period coincides with a significant increase in the educational level of the workforce and a strong decline in wage dispersion. Another important difference is that, in contrast to most other studies, we control for composition effects and provide wage inequality series adjusted for changes in skill (education and experience) composition of the workforce, as in Lemieux (2006).

An important limitation is that we do not examine the evolution of very high wages, such as those in the top percentile of the wage distribution, as the labour force surveys we use are unlikely to provide accurate measures of earnings at the highest percentiles. ${ }^{8}$ In addition, it is unclear whether the supply and demand models used in this paper can explain the evolution of very high wages at the top of the distribution.

\section{I) Data and Descriptive Statistics}

\section{Overview of Data Sources}

Our basic microdata on wages and education come from the French Labour Force Survey (LFS)

Enquête Emploi 1990-2002 and the redesigned LFS from 2003 to 2008, which enables us to

\footnotetext{
${ }^{6}$ Our approach is also related to work by Jeong et al. (2012) for the US and Wasmer (2001a) for the US and France, that emphasise the consequences of changes in the supply of experience related to demographic factors. However, in contrast to the evolution of the supply of education, demographic changes were quite similar in France, the US and Germany (see Wasmer (2001b) for a detailed discussion). As a result, it is unlikely that differences in the supply of experience can explain a significant share of the large differences in wage inequality observed among these countries. In addition, the respective roles of the supply of experience and of education are empirically difficult to disentangle. An increase in the education levels of young workers changes the wage profile across cohorts and thus the return to experience. This implies that in practice changes in the returns to experience over time cannot be distinguished from changes in wages at the cohort level, using cross-sectional data (see, e.g., Borjas (2013) or Glenn (1976) ).

${ }^{7}$ We use wage data up through 2008, while the final year of data available to Card et al. (1999) was 1989, and for Goux and Maurin (2000) and Wasmer (2001a), it was 1993.

${ }^{8}$ See Piketty (2001) or Landais (2007) for top incomes in France and Amar (2010) or Godechot (2012) for the evolution of very high wages.
} 
track changes in the wage structure on a yearly basis after $1990 .{ }^{9}$ To document changes in earlier periods, we complement the LFS series with the survey Training and Professional Qualification (in French, Formation et Qualification Professionnelle, hereafter FQP), which contains information on annual earnings and educational attainment in 1969, 1976 and 1984. Our sample includes all men aged between 16 and 65 years with levels of potential experience of between 1 and 40 years. We measure potential experience using the declared year of completion of studies, which is available in both surveys. In our baseline results with the LFS data, we use monthly wages of male employees working full-time and exclude the self-employed. ${ }^{10}$ For the FQP, we restrict our sample to full-time, full-year employees, as only annual earnings are available. ${ }^{11}$ These differences in wage definition might create a break in our series, which is important to bear in mind.

We investigate the robustness of our results by using restricted access administrative data at the individual level from the DADS-EDP Panel for the period 1991-2008, that report annual earnings across workers for each employer. ${ }^{12}$ While the FQP and LFS are nationally representative samples, civil servants and several sectors that account for approximately $20 \%$ of the workforce during the 1990s are excluded from the DADS, which may affect the measured level of wage dispersion. ${ }^{13}$ Additional details on the construction of the various samples are provided in Appendix 1.

\footnotetext{
${ }^{9}$ Microdata from the LFS are available for the period since 1968, but wage data are only available as categorical variables from before 1990 and were not collected before 1981. A minor issue is the transition to the redesigned LFS in 2003. We have attempted, whenever possible, to harmonize our variable definitions. The LFS is reasonably consistent over time, and we do not find evidence of major discontinuities between 2002 and 2003.

${ }^{10}$ This restriction is traditional in longitudinal studies that use a long time span (see, e.g., Katz and Murphy (1992) ). Excluding part-time workers enables us to obtain a measure of wage changes not affected by measurement errors in the number of work hours related to changes in the method of data collection.As with the CPS in the US, wage data from the LFS and FQP are self-reported data from household surveys.

${ }^{11}$ As with the CPS in the US, wage data from the LFS and FQP are self-reported data from household surveys.

${ }^{12}$ The DADS-EDP panel matches information from two data sources: the DADS administrative wage data and the EDP, a survey with information on education not available in the DADS data. DADS data are collected from compulsory fiscal declarations, which must be made annually by all employers. See Abowd et al. (1999) or Buchinsky et al. (2003) for a more detailed description.

${ }^{13}$ In particular, civil servants and several large public sector firms, such as French National Rail or the French National Electricity Company, are excluded.
} 


\section{Changes in Labour Market Characteristics}

In Table 1, we briefly summarise the major changes in individual worker characteristics and economic conditions that may have affected the wage distribution between the 1960 s and $2008 .{ }^{14}$

While annual GDP growth averaged 5\% before 1975, average growth rates have significantly declined in recent decades. Table 1 documents the substantial decline in the employment rates of workers younger than 25 and older than 55, which followed the economic slowdown. Finally, the minimum wage increased dramatically after 1970, when it was indexed to changes in the average wage and inflation. ${ }^{15}$

Panel B of Table 1 presents shares of the workforce characterised by four basic levels of education. ${ }^{16}$ In contrast to the US (Goldin and Katz 2008, p.196), during the 1950s and much of the 1960s, educational attainment at the high school level and above stagnated. ${ }^{17}$ France traditionally had a relatively elitist educational system: the share of high school graduates in the workforce in France was only $9 \%$ in 1962, compared with $70 \%$ in the US at the beginning of the 1960s (Goldin and Katz 2008, p.196). These elitist policies changed dramatically thereafter during two major reforms. ${ }^{18}$ A first important reform, which occurred in 1959, increased compulsory schooling age from 14 to 16 years for cohorts born after $1953 .{ }^{19}$ As a result, from 1968 to 1975 , the shares of high school and university graduates increased rapidly, following which, from 1975 to 1990 , growth in the supply of skills slowed considerably.

From 1990 to 2008, a second acceleration in educational expansion followed the creation of a new high school diploma (technological and professional Baccalauréats), providing

\footnotetext{
${ }^{14}$ To use the most comparable data possible, we use only the LFS, supplemented by the 1962 Census.

${ }^{15}$ By law, the minimum wage is fully indexed to the price index and half of the annual increase in the blue-collar hourly wage rate. The government also frequently adds discretionary increases (coups de pouce). See Cette et al. (2013) for a detailed decomposition of the increases in the minimum wage over the period.

${ }^{16}$ See the Appendix for details regarding the construction of the educational categories.

${ }^{17}$ Estimates of Estrade and Minni (1996) indicate that the share of the population aged 25-35 with a level of education greater than or equal to high school graduation increased only from $8 \%$ in 1945 to $10 \%$ in 1965.

${ }^{18}$ See Maurin (2007) and Gurgand and Maurin (2006) for a detailed presentation of French educational policies over this period.

${ }^{19}$ This implies that the increase in the number of students related to the reform only occurred after 1967.
} 
unrestricted access to university studies. ${ }^{20}$ This reform had tremendous effects on university graduation rates: the number of post-baccalaureate students increased by $45 \%$ from 1980 to 1990 and by $26 \%$ from 1990 to 2000 .

To put these figures in perspective, Figure 1 depicts the evolution of the log of the ratio of skilled to unskilled workers in France and in the US and UK, from Card and Lemieux (2001), for young workers aged 26-30 years, normalised with respect to the first year of data available. The figures highlight the substantial differences in the growth of education supply across countries in this period. While the relative level of education of young workers in the US labour force stagnated in recent years, it increased rapidly in France during both the 1970s and the 1990s.

\section{II) Key Facts on the Changes in the French Wage Structure}

Next, we describe the major changes in wage inequality in France. Following the literature, we distinguish between developments at the top and bottom ends of the wage distribution by using $\log$ wage differences between the $90^{\text {th }}$ percentile and the median (P90-P50) and between the median and the $10^{\text {th }}$ percentile (P50-P10), which we refer to as upper-tail and lower-tail inequality, respectively. ${ }^{21}$

\section{Trends in Overall Inequality}

We begin by presenting the basic facts in Figure 2, which plots the evolution of upper- and lower-tail inequality from 1950 to 2008 , estimated using the published DADS table of the

\footnotetext{
${ }^{20}$ In 1985, the government declared an official objective of a per cohort high school graduation rate of $80 \%$ over the next 10 years. These new degrees had less stringent academic requirements than the previous high school diplomas, and most graduates receiving these new degrees pursued higher education. By 2010, approximately $70 \%$ and $22 \%$ of technological and professional Baccalauréats graduates, respectively, continued to pursue higher education Vitry (2010), p.199).

${ }^{21}$ Results using the standard deviation of log wages are qualitatively similar to the evolution of the P90-P10 log wage gap and are available upon request.
} 
French Statistical Institute (INSEE). Two clear patterns emerge from these figures. First, wage inequality has varied widely in France since 1950, and France has not always been a country with low or declining levels of wage inequality. From 1950 to 1965, a period of rapid economic growth and stagnation in the supply of education, both upper- and lower-tail wage inequalities expanded considerably, by 12 and $22 \log$ points, respectively.

Second, in sharp contrast, the figures indicate a substantial narrowing of the wage structure after 1970. Lower-tail inequality decreased continuously during the 1970s and 2000s and remained relatively flat after 1983 and during much of the 1990s. Simultaneously, upper-tail inequality increased slightly from 1980 to 1990 and remained broadly flat during the first part of the 1990s and after 2002.

The robustness of the previous results is illustrated in Table 2, which compares lowerand upper-tail inequality measures from FQP-LFS and DADS in selected years in which both DADS data and FQP-LFS data are available for various sample definitions. Reassuringly, both DADS in column 1 and the baseline FQP-LFS series in column 2 indicate very similar trends. Although the measured wage dispersion is higher in the DADS data, most of the differences between the two series reflect, to a large extent, the exclusion of civil servants and large public firms from the DADS sample. ${ }^{22}$

Column 3 shows the results of restricting the sample to workers aged 25-55 to account for the large decline in employment rates experienced by young and old workers documented in Table 1. For this sample, we observe a slightly larger decline of $17 \log$ points in upper tail inequality, while lower tail inequality declines by approximately $9 \log$ points from 1969 to 2008 .

\footnotetext{
${ }^{22}$ When we exclude workers from the public sector in the LFS data to match the composition of the population in DADS, we obtain very similar levels of upper-tail inequality from both sources, with LFS estimates yielding, for example, 0.70 in 2000 and 0.72 in 1990 for the P90-P50 log wage gap.
} 
Column 4 shows wage inequality series, using hourly wages for workers aged 25-55 years for the period 1990-2008, thus including part-time workers in the sample. ${ }^{23}$ At the bottom of the distribution, there is essentially no difference between hourly and monthly wage inequality. ${ }^{24}$ In contrast, upper tail inequality exhibits a stronger decline of $12 \log$ points from 1990 to 2008. A simple decomposition indicates that the decline in the number of hours worked by workers in the middle of the distribution due to the 35-hour workweek explains most of the larger decline in hourly wage inequality over the period (detailed results are available upon request).

\section{Effect of selection into employment}

A first important question is whether the decline in inequality is explained by changes in labour force participation. If selection into employment is non-random, this selection may affect wage inequality simply because selected groups of workers would not feature in the wage distribution.

To investigate this issue, we follow Neal and Johnson (1996) and Olivetti and Petrongolo (2008) in conducting several exercises that involve hourly wage imputations for unemployed workers. ${ }^{25}$ As in Olivetti and Petrongolo (2008), to obtain information about the missing wages of unemployed workers, our imputation techniques exploit the fact that the LFS is a rotating panel. ${ }^{26}$ For each unemployed worker, we compute the average of wage observations from other

\footnotetext{
${ }^{23}$ Information on the construction of hourly wages is provided in Appendix 1.The sample is restricted, as above, to workers aged 25-55 to avoid including students working part-time and encountering problems with changes in the employment rates of old workers. We also restrict the sample to the period 1990-2008, as we cannot compute hourly wages with FQP data.

${ }^{24}$ The fraction of part-time workers among male workers has not changed substantially in recent decades, increasing slightly from $4 \%$ in 1990 to $6 \%$ in 2008 ( Amar et al. (2011) ). However, following the implementation of the 35-hour workweek at the beginning of the 2000 s, the average number of hours worked decreased by approximately one and a-half hours between 1995 and 2005 for blue-collar workers, while it remained unchanged for white-collar workers (see Afsa et al. (2003), Amar et al. (2011)).

${ }^{25}$ One advantage of this approach is that it does not require assumptions about the actual levels of missing wages or the imposition of somewhat arbitrary exclusion restrictions that are necessary to estimate selection correction models. We exclude individuals who are out of the labor force and only impute wages for the unemployed. As highlighted in Table 1, the share of individuals out of the labor force has remained constant over the period for workers aged 25-55.

${ }^{26}$ From 1990 to 2002, each individual was interviewed in March in three consecutive years, while after 2002, two consecutive interviews that requested information on earnings occurred 18 months apart. Through this procedure, we obtain wage data for approximately $31 \%$ of the unemployed workers in our sample.
} 
surveys, when available, and impute this average to unemployed workers. For unemployed workers for whom we did not recover any wage information, we impute a log wage of zero. ${ }^{27}$ As previously, we use hourly wages and focus on the 25-55 age group.

Column 5 presents the wage inequality series obtained using these imputation procedures. For upper tail inequality, including unemployed individuals in the sample has trivial effects and does not affect the previously observed decrease. The situation is quite different for lower tail inequality, where selection into employment plays a more important role. The measured levels of lower tail inequality are between 8 to $10 \log$ points larger with the imputed sample. Nonetheless, the trends appear to be similar: lower tail wage inequality remained stable over the 1990s and then decreased during the 2000s by approximately 6 points.

\section{Effects of Changes in Distribution of Education and Experience}

Another composition effect is related to the change in the distribution of education and experience among employed workers. As the education level has increased significantly during this period, it is potentially necessary to isolate the changes related to the composition of the labour force from changes in the wage structure. To do so, in Column 6 of Table 2, we provide the counterfactual distributions of inequality that would have prevailed if the distribution of education and potential experience across 32 groups had remained at its 1984 level. ${ }^{28}$ These counterfactual distributions were obtained using the reweighting approach proposed by DiNardo et al. (1996), which is simple to implement when the data can be divided into cells of education and experience groups. ${ }^{29}$

\footnotetext{
${ }^{27}$ This imputation procedure provides correct estimates of lower tail inequality if the potential wages of all unemployed workers for whom we impute zero log wages are below the first decile and below the median for upper tail inequality, regardless of the specific values of the imputed wages.

${ }^{28}$ We use 4 groups of education and 8 groups of potential experience. Potential experience is obtained by using the declared year of end of studies when available (90\% of observation) and by imputing it when it is not available. See Appendix for details.

${ }^{29}$ We calculate weights for each group of education and experience such that the reweighted distribution of education and experience in a
} 
The figures reveal a much larger decline in wage inequality when changes in the composition of the labour force are taken into account. Holding the distribution of education and experience constant at 1984 levels, the P90-P50 and the P50-P10 log wage gaps would have declined by 36 and 18 log points, respectively, from 1969 to 2008. Composition effects, which are the difference between the actual and the counterfactual wage inequality series, are found to be positive for most of the period after 1984. This implies that composition effects related to changes in the distribution of education and experience in the population account for most of the stability of P90-P50 during the period.

\section{International Comparisons}

How do the previous findings compare with developments in other countries? Table 3 reports wage inequality measures from recent important studies of Germany, the UK and the US. ${ }^{30}$ The figures reflect the well-known fact that the last thirty years have been a period of rising wage inequality both at the top and bottom of the wage distribution in the US, the UK and Germany. In contrast, wage inequality in France has moved in the opposite direction.

Interestingly, the relative rankings of wage inequality measures across countries have changed over time: upper-tail wage inequality was higher in France than in the US or the UK until the beginning of the 1990s. In contrast, the relatively low levels of wage inequality observed in the US and UK during the 1960s and 1970s were not observed in France during this period. Only after 1977 did lower-tail inequality become lower in France than in the US. Finally, despite the increase in overall wage inequality in Germany, Germany still appears to have a lower level of wage inequality than France in 2000.

given year is equal to that of the reference year. The "counterfactual" distribution is obtained simply by using the weights to estimate the deciles. See DiNardo et al. (1996) for details on the theoretical basis of the decomposition model.

${ }^{30}$ Due to the censoring of high-wage earners in the available data, Dustmann et al. (2009) report the P85-P50 gap for Germany instead of the P90-P10 gap. Additional series can also be found for many other countries and from alternative sources in Atkinson (2008). 


\section{III) Changes in between and within group wage inequality}

Changes in the overall wage distribution reflect both changes in average wages across skill groups and changes in wage dispersion within skill groups. It is theoretically important to know the relative importance of each factor, as their trajectories are not explained by the same mechanisms. In this section, we examine the respective roles of changes in between- and withingroup wage inequality.

\section{Trends in the between-group wage differentials}

As in most of the literature (see, e.g., Katz and Murphy, 1992, and Card and Lemieux, 2001), we describe the evolution of changes in education returns by focusing on two education groups that can be used to illustrate changes in the relative prices of "skilled" versus "unskilled" labour. We define the "skilled group" by pooling high school and university graduates, while the "unskilled group" is defined by pooling individuals with educational attainment below the high school level.

Column 1 in Table 4 underscores that the skill premium, measured by average monthly wages, declined sharply, by $36 \log$ points, over the period. ${ }^{31}$ Column 2 shows the skilled premium estimated using median hourly wages from 1990 to 2008 for workers with experience of between 5 and 35 years. The patterns are broadly similar. In Column 3, we take into account changes in employment probability by imputing wages of unemployed workers, following the procedure described above. With respect to Column 2, the skill premium is almost unchanged.

\footnotetext{
${ }^{31}$ To control for changes in the demographic compositions of these groups, the estimated skill premium displayed is calculated using a fixed weighted average, estimated separately for eight experience groups and using weights from the distribution of experience in 1990, as in Autor et al. (2008).
} 
An important observation is that the skill premium did not change similarly across experience groups. We illustrate this in Figure 3, which plots the skill premiums for potential experience groups of 1 to 5,11 to 15,21 to 25 and 31 to 35 years with the change in the relative supply for each group, which is simply the log of the ratio of the number of skilled to unskilled workers. The figure shows that changes in the skill premium differed substantially across experience groups in recent decades. While the earnings gap decreased for all groups, the decrease began much earlier (after 1990) for lower-experience groups, with 1 to 5 years of experience, than for other groups. Consistent with the view that there is a relationship between the relative wage and the supply of skills across each experience group, the skill premium for younger workers decreased much more substantially than for other workers in recent years. This suggests that fluctuations in supply within experience groups may have played an important role in the decline of the skill premium.

\section{Trends in Residual Inequality}

We first estimate residual wage inequality with the residuals from a regression of the $\log$ of monthly wages of full-time workers, using the 32 education and experience cells described above. Column 4 in Table 4 shows that residual upper-tail inequality remained remarkably flat after 1976. Similarly, Column 5 shows that residual lower tail inequality remained stable from 1990 to 2008, following a decrease of $7 \log$ points between 1976 and 1990. Columns 6 and 7 report an alternative measure of residual inequality, obtained using the weighted average of within-group wage dispersion. This measure is obtained by using the share of the cell in the labour force as weights. The results are virtually identical.

In sum, it is clear from the above results that changes in residual wage dispersion play little role in explaining the recent changes in wage inequality in France. While changes in 
residual inequality account for a large share of the overall growth in wage inequality in the US or the $\mathrm{UK}^{32}$, this is not the case in France. Most changes in the French wage structure are related to changes in between-group inequality, particularly the decline in the skill premium. The fact that residual inequality remained stable is surprising, given that in most countries within- and between-groups inequality have moved together. ${ }^{33}$

\section{IV) Relative Supply of Education and the Skill Premium}

In this section, we investigate the degree to which the dramatic increase in the supply of education in France can explain the large decline in the skill premium. To do so, we build on the standard supply-demand framework of Card and Lemieux (2001).

\section{The model}

The economy is composed of two skill groups such that $N_{H t}$ is the aggregate high-skill labour input and $N_{L t}$ is the aggregate low-skill labour input. As previously, we define skilled workers as individuals with a university or a high school degree, while unskilled workers have less than high school education. Assume the economy can be represented with a nested constant elasticity of substitution (CES) production function:

$$
Y_{t}=\left(\lambda_{t} N_{H t}^{\rho}+\left(1-\lambda_{t}\right) N_{L t}^{\rho}\right)^{\frac{1}{\rho}}
$$

where $Y$ is output, and $\rho=1-\frac{1}{\sigma}$. The parameter $\sigma$ is the elasticity of substitution between each type of labour, while $\lambda_{t}$ measures relative technological progress. We assume that there is

\footnotetext{
${ }^{32}$ See, e.g., Juhn et al. (1993) for the US and Gosling et al. (2000) for the UK.

${ }^{33}$ This pattern is not consistent with theoretical insights of Acemoglu (1999), predicting that residual wage inequality should increase following an increase in the education level of the workforce. This is due to the fact that firms might create more high-skilled jobs characterized by higher wage dispersion in response to an increase in education supply.
} 
imperfect substitution between education and experience groups within the high- and low-skill labour inputs, such that

$$
N_{d t}=\left[\sum_{j}\left(\alpha_{d j} N_{d j t}^{\eta}\right)\right]^{\frac{1}{\eta}}
$$

where $N_{d j t}$ is the aggregate labour input of experience groups $j$ in skill group $d, \eta=1-\frac{1}{\sigma_{x}}$, where $\sigma_{x}$ is the elasticity of substitution between experience groups, and $\alpha_{d j}$ are assumed to be fixed across groups and are normalised so that $\sum_{j} \alpha_{d j}=1$. If wages are set competitively and the economy is assumed to operate on the demand curve, the log of the skill premium in a given experience group $j$ is given by:

$$
\ln \frac{W_{H j t}}{W_{L j t}}=\ln \left(\frac{\lambda_{t}}{1-\lambda_{t}}\right)+\left(\frac{1}{\sigma_{x}}-\frac{1}{\sigma}\right) \ln \left(\frac{N_{H t}}{N_{L t}}\right)+\ln \frac{\alpha_{H j}}{\alpha_{L j}}-\left(\frac{1}{\sigma_{x}}\right) \ln \frac{N_{H j t}}{N_{L j t}}
$$

where $W_{H j t}$ and $W_{L j t}$ are the wages of skilled and unskilled workers, respectively. Similarly, the skill premium at the aggregate level in a given year is given by:

$$
\ln \frac{W_{H t}}{W_{L t}}=\ln \left(\frac{\lambda_{t}}{1-\lambda_{t}}\right)-\frac{1}{\sigma} \ln \frac{N_{H t}}{N_{L t}}
$$

Equations 1, 2 and 3 form the basis of our empirical implementation.

\section{Empirical Implementation}

The estimation of a 2-level nested CES is complicated by the fact that the aggregate indexes $N_{H t}$ and $N_{L t}$ in Eq. 3 depend on the lowest-level substitution parameter $\sigma_{x}$ and the relative efficiency parameters $\alpha_{d j}$, which must be estimated. This implies that we must begin at the 
lower level of aggregation, using Eq. 2 to estimate $\sigma_{x}$. The standard strategy is to absorb the effect of the common factors affecting the skill premium using a year fixed effect for the first two terms and a group fixed effect for the third term in Eq. 2. This leads to the following regression model:

$$
\ln \left(\frac{W_{H j t}}{W_{L j t}}\right)=\gamma_{t}+\gamma_{j}+\gamma_{1} \ln \left(\frac{N_{H j t}}{N_{L j t}}\right)+\Gamma_{j} \text { RealMinWage }_{t}+\epsilon_{j t}
$$

where $\gamma_{j}$ and $\gamma_{t}$ are the experience and year effects, respectively. The parameter $\gamma_{1}$ provides a direct estimate of $-1 / \sigma_{x}$, the elasticity of substitution. The model also includes flexible controls for changes in the minimum wage through an interaction between the minimum wage in real terms and each potential experience or age group.

Using estimates of $\sigma_{x}$, the efficiency parameters $\alpha_{d j}$ can easily be obtained with the $\operatorname{expression}^{34}$ :

$$
\ln W_{d j t}+1 / \sigma_{x} \ln N_{d j t}=\eta_{d t}+\ln \alpha_{d j}
$$

where the right-hand side and group specific factors can be estimated using a set of time and age dummies. Combining estimates of $\alpha_{d j}$ and $\sigma_{x}$, we construct the aggregate supply indexes $N_{H t}$ and $N_{L t}$, using Eq. 1, which we can use in Eq. 3 to estimate $\sigma$.

We follow Katz and Murphy (1992) and absorb the effect of the technology parameter $\lambda_{t} /\left(1-\lambda_{t}\right)$ by including a time trend in the model. We also follow Autor et al. (2008) and include the unemployment rate and the minimum wage as additional control variables:

$$
\ln \left(\frac{W_{H t}}{W_{L t}}\right)=\beta_{0}+\beta_{1} t+\beta_{2} \ln \left(\frac{N_{H t}}{N_{L t}}\right)+\beta_{3} \text { RealMinWage }_{t}+\beta_{4} \text { Unemp }_{t}+\epsilon_{t}
$$

\footnotetext{
${ }^{34}$ This expression comes straightforwardly from the first-order conditions. See Card and Lemieux (2001) for details.
} 
As in Goldin and Katz (2008, p.295) and Card and Lemieux (2001), among others, and under the assumption that the relative skill supplies are predetermined in the short run, we estimate the above models with OLS. ${ }^{35}$ Additional details on data construction are given in the Appendix.

\section{Elasticity between experience groups}

We start at the experience group level to estimate the elasticity $\sigma_{x}$ from Eq. 4 . Columns 1 and 2 of Table 5 present the results, using annual LFS data from 1990 to 2008 . The models are first estimated using potential experience groups, as in Autor et al. (2008). The results indicate strong evidence of imperfect substitution between age and experience groups. In Column 1, we find a statistically significant parameter estimate of -0.08 , implying an elasticity $\sigma_{x}$ of 12.2 . In Column 2, in addition to time and year fixed effects, the model includes flexible controls for changes in the minimum wage. The estimated parameter is unchanged. In Column 3, as in Card and Lemieux (2001), we use 7 age groups from 21 to 55 years to define cells instead of potential experience, obtaining a slightly lower point estimate that suggests an elasticity of $13.1 .^{36}$

In Columns 4 and 5, we examine whether the results are robust to the use of alternative wage data from the DADS-EDP dataset for the 1991-2008 period. With these data, we can also assess the effect of the restriction to full-time full-year workers, as this dataset contains relatively high-quality information on the number of days worked and total pay. Column 3 uses the annual wages of full-time, full-year workers, while Column 4 uses daily wages, including those of all workers with at least one positive employment spell per year. In both columns, point estimates

\footnotetext{
35 This is consistent with the evidence of Magnac and Thesmar (2002) that much of the educational expansion of the 1990s was driven by exogenous policy changes.

${ }^{36}$ Theoretically, using experience groups appears to be more appropriate, given that future university graduates aged 18-24, who may still be attending university, are quite unlikely to be substitutable with high-school drop-outs of the same age. We use 7 age groups betwee the ages of 21 and 55 .
} 
are statistically significant and substantially larger than those obtained with the LFS sample. The columns indicate elasticities of substitution of 9.1 and 11, respectively.

In Column 6, we exploit variations from a longer time period by combining annual observations from 1969, 1976, 1984, 1990, 1995, 2000, 2005 and 2008 from both the FQP and LFS datasets. ${ }^{37}$ The parameter is slightly lower but still strongly statistically significant, with an elasticity of substitution of 13.7 .

Table 6 presents several alternative specifications designed to check the robustness of the previous estimates. Column 1 estimates the model with a skill premium in which high school graduates have been allocated to the low skill group. We obtain an elasticity of approximately 10, which suggests that our results do not depend on the assumption that high school graduates belong to the skilled group. ${ }^{38}$

An important issue concerns the additional complexity introduced by the minimum wage. The effects of the minimum wage might not be completely absorbed by the controls included in the previous model if, for example, the effects of the increases in the minimum wage vary over time. A partial solution is to reestimate the model, using only workers with more than 5 years of labour market experience which eliminates a large share of workers earning the minimum wage. ${ }^{39}$ We also exclude workers with levels of potential experience above 35 years, as changes in the skill premium for this group may reflect changes in participation rates over time. In addition, we use median hourly wages and include part-time workers in the sample used to calculate the skill premium. Median wages are, unlike average wages, not directly affected by the minimum wage, as the median worker is never paid the minimum wage. In Column 2, the

\footnotetext{
${ }^{37}$ We do not use all years after 1990 in this specification to avoid giving too much weight to recent changes in the wage structure.

${ }^{38}$ Another issue is the creation of the new high school diploma during the 1990s, which might have altered the composition of the high-

school group, making comparisons over time problematic. However, we have estimated the model, including in the skill group only

workers with a 'traditional' high-school diploma, and obtained similar results.

${ }^{39}$ The share of workers in the low skill groups, with wages below the minimum wage plus 5\%, is always less than $5 \%$ in cells containing workers with between 5 and 35 years of potential experience.
} 
parameter estimated using median hourly wages remains strongly statistically significant, with an elasticity of substitution of 12.8. Using the median wage also simplifies the task of accounting for potential selectivity bias. In Column 3, we use a skill premium calculated by including imputed wages for unemployed workers in the sample, following the imputation procedure described in the previous section. The results are nearly unchanged. ${ }^{40}$

Thus far, we have followed most papers in the field by estimating the above model using OLS. ${ }^{41}$ However, endogeneity of the relative supply might be a concern if, for example, the slowdown in the increase in the educational level during the 2000s was a response to the decline in the skill premium during that period.

We construct an instrument based on the hypothesis that, for cohorts who entered the labour market at the end of the 1980s, differences in graduation rates are, as argued by Magnac and Thesmar (2002), more likely to reflect the effect of the policy change than be an endogenous response to changes in the skill premium. ${ }^{42}$

The instrument is a dummy variable separating cohorts that entered the labour market before or after 1985, the year that the new high school diploma was implemented. The instrument aims to capture average differences in graduation rates between the two groups, differences that are likely to reflect the policy change. ${ }^{43}$ The short-run effect of the reform was large: in 1990, the relative skill supply of the treated group was $0.7 \log$ points higher than that of

\footnotetext{
${ }^{40}$ In one set of results, we also examined the effect of payroll tax subsidies in place since the early 1990s for minimum-wage workers receiving between 1 and 1.2 times the minimum wage Kramarz and Philippon (2001). Changes in the payroll tax for unskilled workers may have a confounding effect on our estimates because the LFS, FQP and DADS datasets do not include employer-paid contributions. However, workers covered by these deductions represent a small share of our sample-only $4 \%$ on average and never more than $15 \%$ of workers in the low skill group when the sample is restricted to workers aged 25-55. In an attempt to check the robustness of our estimates, we have estimated models in which gross wages are imputed, using the value of the net wage computed from the data. We find that doing so only marginally changes the results.

${ }^{41}$ There is no standard and credible instrument available in the literature to distinguish variations in the aggregate skill supply within experience groups from their correlations with unobserved factors influencing the skill premium. This explains why most papers estimate the model using OLS.

${ }^{42}$ Such a cohort-based approach to identifying the impact of education on wages has been used in France in a different context by Maurin and McNally (2008) and Grenet (2013).

${ }^{43}$ The "treated" group consists of workers with experience levels of from 1 to 5 years in 1990 and who thus would have been affected by the reform. The second group consists of workers with experience levels of from 5 to 10 years in 1990 and groups with more experience and who thus theoretically would have graduated from high school before the reform. See the appendix for details.
} 
the untreated group, reflecting the fact that the share of skilled workers is $48 \%$ in the treated cohort compared with $31 \%$ in the non-treated cohort. To exclude the effects of changes in the compositions of experience groups over time, we track cohorts by using a sample with 5-years intervals when possible, thus including only 1990, 1995, 2000, 2005 and 2008.

As a reference, Column 4 presents OLS estimates using this restricted sample, with results similar to those found for the previous models. Column 5 presents the IV estimate. The instrument is reasonably strong, with a first stage F-statistic above 15 . The estimated elasticity is also statistically significant and slightly larger than in the previous estimates, with a value of 7.9. However, even if IV estimates are measured relatively precisely, they are not significantly different from the corresponding OLS estimates in Column $4 .^{44}$

\section{Elasticity between aggregate skill groups}

We now turn to estimating the elasticity of substitution between aggregate groups $\sigma$. Panel A in Table 7 presents several regression models based on Eq. 6 for the aggregate skill premium. ${ }^{45}$ The first column includes only the relative supply index with a time trend, as in Katz and Murphy (1992). The estimate of the parameter of the relative supply is relatively large, indicating an elasticity of 3.5, but it is not statistically significant. In Columns 2 and 3, we additionally include controls for the minimum wage and the unemployment rate. The minimum wage has a positive sign, which is difficult to interpret, while the effect of the unemployment rate is also positive and statistically insignificant. The model in column 3 indicates an elasticity of 5, with a very large

\footnotetext{
${ }^{44}$ We also estimated a model using a sample that includes only the two closest cohorts that were 'treated' and 'not treated' by the reform, that is, those with experience of 1 to 5 years in 1990 and those with experience of 5 to 10 years in 1990. By focusing only on these two groups, the sample size decreases dramatically. However, these two cohorts may be quite homogenous, and variations in education supply between them are more likely than with the full sample to strictly reflect the effect of the policy change. Our parameter estimate is similar to that of the previous results, with an estimated elasticity of substitution of 12 .

${ }^{45}$ As in Table 4, the skill premium is a fixed weighted average, using the share of experience groups from 1990 to control for changes in composition. The relative supply index used to estimate the aggregate supply is obtained using Eq. 1 , assuming an elasticity of substitution $\sigma_{x}$ of 11. See Appendix for details. Calculation of indexes, assuming values of $\sigma_{x}$ of 9 or 13, produce similar results.
} 
standard error. In column 4, we only include the minimum wage in the sample, and find that it is strongly correlated with the skill premium.

The previous parameters are measured very imprecisely and the results tend to differ across models. Thus, it is difficult to draw firm conclusions from these regressions. This result is in large part explained by the fact that all three dependent variables are strongly correlated: the correlation between the trend and the relative supply index is above 0.9 , while that between the minimum wage and the relative supply index is above 0.7. This implies that relatively little variation is left in the data with which to distinguish the effect of the minimum wage from that of supply in a model that includes a deterministic time trend. While there is some evidence that the aggregate supply of education has affected the overall skill premium, this simple time series model appears to be unable to disentangle the respective effects of the different factors on the wage structure in the French case.

To further explore the relationship between wage inequality, the minimum wage and labour supply, the lower panels B and C provide regression results using upper- and lower-tail inequality for males from the DADS data, which are available annually after 1973. The effect of relative supply is small and statistically insignificant across all specifications, both for P50P10 and P90P10. In contrast, the results indicate that lower-tail inequality is strongly related to changes in the minimum wage. This is illustrated in Figure 4, which shows the predicted and actual values for P50P10, using the simple bivariate model of column 4 that includes only the minimum wage. The fit is remarkable over the period. Reassuringly, we do not find any effect of the minimum wage in regressions explaining the P90P50 log wage gap. ${ }^{46}$

\section{How much can be explained by supply and demand mechanisms at the experience}

\footnotetext{
${ }^{46}$ See also Verdugo et al. (2012) for a detailed analysis of the relationship between the minimum wage and lower tail inequality.
} 
group level?

While there is strong evidence that the minimum wage influenced lower tail inequality, the role of the aggregate supply of education is difficult to estimate, using the Katz and Murphy time series model for a period over which both the minimum wage and the level of education are increasing.

In contrast, we found significant evidence that changes in the experience group specific skill premium are strongly correlated with changes in supply at the group level. Across OLS specifications, we found values of $\sigma_{x}$ between 9 (with the DADS data) and 13 (with the FQPLFS data), while many specifications produce results close to $10 .^{47}$ These values are larger than the values of 3.5 and 5, reported for the US by Autor et al. (2008) and Card and Lemieux (2001), respectively, in their preferred specifications, while for the UK, Manacorda et al. (2012) also report an elasticity of 5. The estimated elasticity is nonetheless close to the elasticity of 8.6 , obtained for Germany by Brücker and Jahn (2011). ${ }^{48}$

Given that the changes in relative supply in France have been large in recent decades, changes in skill supply at the experience group level nonetheless explain a substantial share of the decline of the skill premium within groups. This is illustrated in the upper panel of Table 8 , which decomposes changes in the skill premium into changes explained by the effect of skill supply and a residual. ${ }^{49}$ As a reference, we use the lower and upper bounds of our elasticities, 9 and 13, respectively. Assuming an elasticity of substitution of 9, changes in group-specific supply have decreased the skill premium by between 13 and $25 \log$ points, and assuming an elasticity of substitution of 13 , such changes have decreased the skill premium by between 9 and

\footnotetext{
${ }^{47}$ The range of the estimates does not seem exceptional in the literature: the range of estimates in Card and Lemieux (2001) is also large, running from 3.77 (Table 3, p. 725) to 9.34 (Table 5, p.731).

${ }^{48}$ As all mentionned papers use OLS estimates, we also focus on OLS results in this section to ensure comparability.

${ }^{49}$ The simple decomposition method is formally presented in the Appendix.
} 
$17 \log$ points. This implies that changes in supply within experience groups can account for $33 \%$ to $50 \%$ of the decline in the overall skill premium from 1968 to 2008 , depending on the assumed elasticity of substitution.

In Panel B, we investigate the impact of group specific supply on the wage structure. As for the skill premium, we find that between a third and half of changes in upper tail inequality are predicted by changes in supply. In contrast, changes in supply explain very little of the change in lower tail inequality.

\section{Limitations of the Results}

The assumptions underlying the derivation of the model above are highly restrictive, and thus the results should be interpreted cautiously. One important limitation is that we cannot isolate the component of changes in wages related to changes in the unobservable abilities of workers within groups. The distribution of unobservables within groups is likely to change as graduation rates rise, as argued convincingly for the US by Carneiro and Lee (2011). Accounting for changes in average worker quality within groups over time would require having one or several credible variables that influence education but not wages, which are difficult to find.

Second, as in Card and Lemieux (2001) and most papers in the literature, we have focused on explaining changes in men's earnings. In addition, we did not investigate the impact of the rise in female labour force participation, which is central to the analysis of Wasmer (2001a). This is clearly a very strong assumption that is only valid if men and women are not substitutes in production. To check the robustness of the results, we have estimated models 
including women in both the supply and the skill premium measures. ${ }^{50}$ The results are virtually unchanged and are available upon request.

\section{V) Conclusion}

In this paper, we have documented the evolution of the wage structure in France in recent decades. We have shown that, unlike the US, Germany and the UK, wage inequality did not increase in France, not only at the bottom of the wage distribution but also at the top, between the median and ninth decile, where the minimum wage is less likely to play a significant role. We found that these changes are not explained by composition effects, such as the decline in labour force participation of low-skilled workers, but reflect a decline in the wage premium of skilled workers. Using a model with imperfect substitution between experience groups, we have shown that the substantial increase in the educational attainment of the labour force can explain between a third and half of the observed decline in the skill premium within experience groups. The strong negative covariation between changes in the skill premium and the relative supply of skills within experience groups suggests that supply shifts rather than purely institutional factors such as the minimum wage explain a substantial share of the decline in upper tail inequality.

An important limitation of the present analysis must be emphasised. In the words of Goldin and Katz (2008, p.85), despite the relatively low level of wage inequality in France, "inequality anxieties" in France are remarkably high. According to Maurin (2009) and Algan and Cahuc (2007), a large part of current economic anxieties relates to risks of unemployment and long-term unemployment, which have increased dramatically since the beginning of the 1970s. This suggests that the level of wage dispersion might not currently be the most important dimension of inequality in the French labour market. An interesting direction for future work

\footnotetext{
${ }^{50}$ Implicitly, this amounts to assuming that men and women are perfect substitutes within education and potential experience groups.
} 
might thus be to investigate how the distribution of unemployment risks across workers has shifted in recent decades.

\section{Appendix}

\section{Construction of the wage data:}

FQP/LFS: In the LFS, salaries relate to the previous monthly earnings (usually March), while FQP respondents are asked to report their exact payroll earnings the year prior to the survey and the number of months of work corresponding to those earnings, with a breakdown into months of full-time and part-time work. For the FQP, we include in our sample respondents declaring that they worked full-time during the whole year; we divide their annual earnings by twelve to obtain a monthly wage. We follow the rest of the literature by removing observations with implausibly low wages that are likely to be measurement errors in both FQP and LFS. We eliminate individuals working full-time whose salary is below the minimum wage minus $20 \%$. In practice, this means removing up to $3 \%$ of individual annual observations over the period. To obtain a real wage, we use the consumer price index to deflate wages in 1998 Euros. Sampling weights are used in all calculations. Our final sample contains on average approximately 50000 annual individual observations from 1990 until 2002 and approximately 30000 for the new LFS. For the FQP, the number of observations is 18500 for 1970, 21600 for 1977 and 20500 for 1985.

Construction of the Hourly Wage Series with LFS: For the LFS series from 1990 to 2002, we use the variable $\mathrm{HH}$ which contains the "usual number of hours worked per week". This variable has on average $8 \%$ of missing values each year when a wage is observed. When $\mathrm{HH}$ is missing, we use the median number of hours from the categorical variable DU which contains the "usual number of hours worked" in 4 groups and has no missing values. For the redesigned LFS from 2003 to 2008, we use the variable HHC which contains "the average number of hours per week in the main job". There are only $3 \%$ of missing values. To deal with these missing values, we use the categorical variable DUHAB which reports the "usual number of hours worked".

DADS-EDP data: For each individual, we retain only full-time job spells. We sum the wages and number of days for each job spell. The data are trimmed on both sides to eliminate individuals with wages below the first percentile and above the 99th percentile. In both DADSEDP and LFS-FQP, wages are reported before income taxes are deducted.

\section{Definition of education, skill groups and experience:}

Education: In Table 1, we start with four basic education groups: primary schooling, secondary schooling, high-school graduates and university graduates. By primary schooling level, we denote those reporting only basic levels of education; by secondary schooling, we denote those who completed at least three years of study after primary school. We call students who passed a national examination, the baccalaureate, high school graduates. Entrance to higher education is restricted to those who have passed this national examination. University graduates are those with at least two years of study at the post-high-school level. 
Potential Experience: Labour market experience is measured as the age of the individual minus the reported age of entry into the labour force. For individuals for whom this value is missing (approximately 9\%), we assume that those with primary, secondary, high school, and college education enter the labour market at 15, 16, 19, and 22 years of age, respectively. We restrict the analysis to individuals with between 1 and 40 years of labour market experience. For each education level, we group individuals into 8 different 5-year experience groups: 1-5, 6-10, 11-15, 16-20, 21-25, 25-30, 31-35, 35-40. In the DADS-EDP data, age of entry in the labour market is not available, so we impute the age of entry in the labour force, using diploma dates and the previously described rule.

Skilled/Unskilled workers (Table 4, columns 1-3): Skilled workers are defined by pooling workers who are either high school or university graduates. Unskilled workers are workers with a below high school level of education.

Calculation of the fixed-weight overall skill premium: We first calculate differences in average wages between skilled and unskilled workers within experience groups. To control for changes in the composition of the labour force across experience groups, the skill premium is obtained as the weighted average of experience specific skill premia. We obtain fixed weights by using the shares of experience groups in 1990. We follow a similar procedure for the median skill premium, using instead differences in median wages.

Construction of the skill premium at the experience group level used as a dependent variable in tables 5 and 6: The skill premium is the difference between the average wage of skilled and unskilled workers except when otherwise indicated.

Construction of the supply index: At the experience group level, the supply index is the log of the ratio between the number of workers in the labour force in the cell in the skilled and the unskilled group. The data come from FQP and the LFS. The aggregate supply index is calculated using Eq. 1 for each skill group. We use estimates of $\alpha_{d j}$ obtained from Eq. 5, estimated with an elasticity $\sigma_{x}$ of 11 . To estimate $N_{d j t}$, we use the number of workers in the labour force in a particular experience group $j$ in skill group $d$.

Age group (Table 5, column 3): We restrict the sample to ages 21-55 and use 7 different 5-year age groups: $21-25,26-30,31-35,36-40,41-45,46-50,51-55$.

\section{Instruments (Table 6):}

Construction of the instrument based on policy change (Table 6, column 5): The instrument is a dummy variable indicating whether an education or experience group in a given year entered the labour market after 1985 interacted with a trend. In 1990, this group includes workers with experience of less than 5 years; in 1995: less than 10 years; in 2000: less than 15 years; in 2005: less than 20 years; and in 2008: less than 20 years. 


\section{Decomposition (Table 7):}

We use a standard decomposition approach (see Firpo et al. (2009)). Denote $S_{j t}=\ln \left(W_{H j t} / W_{L j t}\right.$ ) as the skill premium and $L_{j t}=\ln \left(N_{H j t} / N_{L j t}\right)$ as the relative skill supply of group $j$. Let $S_{j t}\left(L_{j t}\right)$ be the skill premium observed in period $t$ if the supply of education corresponds to that of period $t^{\prime}$. By definition, when $t=t^{\prime}, S_{j t}\left(L_{j t^{\prime}}\right)$ is the observed skill premium. In our model, $S_{j t}\left(L_{j t}\right)$ is given by Eq. 4. The observed change in the skill premium between 1969 and 2008 can be decomposed by:

$S_{j 08}\left(L_{j 08}\right)-S_{j 69}\left(L_{j 69}\right)=\left(S_{j 08}\left(L_{j 08}\right)-S_{j 08}\left(L_{j 69}\right)\right)+\left(S_{j 08}\left(L_{j 69}\right)-S_{j 69}\left(L_{j 69}\right)\right)$

where $S_{08}\left(L_{69}\right)$ is the counterfactual skill premium that would have been observed, had all other factors, except group specific supply, remained the same. The first term in parenthesis is the part of the change explained by change in supply, while the second term is the residual. By applying Eq. 4, under the simplifying assumption that changes in $\gamma_{t}$ related to changes in specific group supply are negligible, the first term is simply $\left(1 / \sigma_{x}\right)\left(S_{68}-S_{08}\right)$.

For changes in the wage distribution, we follow a similar procedure of applying the previous change to the skill premium within each experience group in the wage distribution of 2008. The explained part is the difference between the observed and the counterfactual distribution in 2008, given the supply of 1969, that we estimate using the elasticity and the change in supply for each experience group.

\section{References}

Abowd, John M., Francis Kramarz and David N. Margolis (1999), 'High wage workers and high wage firms', Econometrica 67(2), 251-334.

Acemoglu, Daron (1999), 'Changes in unemployment and wage inequality: An alternative theory and some evidence', American Economic Review 89(5), 1259-1278.

Afsa, Cedric, Pierre Biscourp and Pascale Pollet (2003), 'La baisse de la duree du travail entre 1995 et 2001', Insee Premiere $\mathbf{8 8 1}$.

Algan, Yann and Pierre Cahuc (2007), La société de défiance: comment le modèle social français s'autodétruit, Éditions Rue d'Ulm.

Amar, Michel (2010), 'Les très hauts salaires du secteur privé', Insee première 1288, 4.

Amar, Michel, Adeline Baudrey and Corrine Prost (2011), 'Les evolutions de l'emploi et des salaires depuis 1990', Emploi et salaires, Editions 2011.

Autor, David H., Lawrence F. Katz and Melissa S. Kearney (2008), 'Trends in u.s. wage inequality: Revising the revisionists', Review of Economics and Statistics 90(2), 300-323.

Blau, Francine and Lawrence Kahn (1996), 'International differences in male wage inequality: Institutions versus market forces', Journal of Political Economy 104(4), 791-836. 
Borjas, George J. (2013), The slowdown in the economic assimilation of immigrants: Aging and cohort effects revisited again, Working Paper 19116, National Bureau of Economic Research.

Brücker, Herbert and Elke J Jahn (2011), 'Migration and wage-setting: Reassessing the labor market effects of migration*', The Scandinavian Journal of Economics 113(2), 286-317.

Buchinsky, Mosche, Gary S Fields, Denis Fougère and Francis Kramarz (2003), Francs or ranks? earnings mobility in france, 1967-1999, CEPR Discussion Papers 3937, C.E.P.R. Discussion Papers.

Card, David, Francis Kramarz and Thomas Lemieux (1999), 'Changes in the relative structure of wages and employment: A comparison of the united states, canada, and france', Canadian Journal of Economics 32(4), 843-877.

Card, David and John E. DiNardo (2002), 'Skill-biased technological change and rising wage inequality: Some problems and puzzles', Journal of Labor Economics 20(4), 733-783.

Card, David and Thomas Lemieux (2001), 'Can falling supply explain the rising return to college for younger men? a cohort-based analysis', The Quarterly Journal of Economics 116(2), 705-746.

Carneiro, Pedro and Sokbae (Simon) Lee (2011), 'Trends in quality-adjusted skill premia in the united states, 1960-2000', American Economic Review 101(6), 2309-49.

Carrasco, Raquel, Juan F. Jimeno and A. Carolina Ortega (2012), Declining returns to skill and the distribution of wages : Spain 1995-2006, Economics Working Papers we1231, Universidad Carlos III, Departamento de Economía.

Cette, Gilbert, Valérie Chouard and Gregory Verdugo (2013), 'Minimum wage and the average wage in France: a circular relationship?', Economics Bulletin 33(3), 1832-1839.

Charnoz, Pauline, Elise Coudin and Mathilde Gaini (2011), Changes in the french wage distribution 1976-2004: Inequalities within and between education and experience groups, Working Papers 2011-23, Centre de Recherche en Economie et Statistique.

Charnoz, Pauline, Elise Coudin and Mathilde Gaini (2013), Une diminution des disparités salariales en France entre 1967 et 2009, Insee Références - Édition 2013, Emploi et salaires. 
DiNardo, John, Nicole M. Fortin and Thomas Lemieux (1996), 'Labor market institutions and the distribution of wages, 1973-1992: A semiparametric approach', Econometrica 64(5), 1001-44.

Dustmann, Christian, Johannes Ludsteck and Uta Schönberg (2009), 'Revisiting the german wage structure', The Quarterly Journal of Economics 124(2), 843-881.

Estrade, Marc-Antoine and Claude Minni (1996), 'La hausse du niveau de formation: la durée des études a doublé en cinquante ans.', Insee Première $\mathbf{4 8 8}$.

Firpo, Sergio, Nicole M. Fortin and Thomas Lemieux (2009), 'Unconditional quantile regressions', Econometrica 77(3), 953-973.

Glenn, Norval D (1976), 'Cohort analysts' futile quest: Statistical attempts to separate age, period and cohort effects', American sociological review 41(5), 900-904.

Godechot, O. (2012), 'Is finance responsible for the rise in wage inequality in france?', SocioEconomic Review 10(3), 447-470.

Goldin, Claudia D. and Lawrence F. Katz (2008), The race between education and technology, Harvard University Press.

Goldin, Claudia and Robert A. Margo (1992), 'The great compression: The wage structure in the united states at mid-century', The Quarterly Journal of Economics 107(1), 1-34.

Goos, Maarten and Alan Manning (2007), 'Lousy and lovely jobs: The rising polarization of work in britain', The Review of Economics and Statistics 89(1), 118-133.

Gosling, Amanda, Stephen Machin and Costas Meghir (1994), 'What has happened to men's wages since the mid-1960s?', Fiscal Studies 15(4), 63-87.

Gosling, Amanda, Stephen Machin and Costas Meghir (2000), 'The changing distribution of male wages in the u.k', Review of Economic Studies 67(4), 635-66.

Goux, Dominique and Éric Maurin (2000), 'The decline in demand for unskilled labor: An empirical analysis method and its application to france', The Review of Economics and Statistics 82(4), 596-607.

Grenet, J. (2013), 'Is it enough to increase compulsory education to raise earnings? evidence from french and british compulsory schooling laws', Scandinavian Journal of Economics .

Gurgand, Marc and Éric Maurin (2006), 'Démocratisation de l'enseignement secondaire et inégalités salariales en France', Annales Histoire Sciences Sociales 61(4), 845. 
Jeong, Hyeok, Yong Kim and Iourii Manovskii (2012), 'The price of experience', KDI School of Pub Policy \& Management Paper (12-09).

Juhn, Chinhui, Kevin M. Murphy and Brooks Pierce (1993), 'Wage inequality and the rise in returns to skill', Journal of Political Economy 101(3), 410-42.

Katz, Lawrence F. and Kevin M. Murphy (1992), 'Changes in relative wages, 1963-1987: Supply and demand factors', The Quarterly Journal of Economics 107(1), 35-78.

Kramarz, Francis and Thomas Philippon (2001), 'The impact of differential payroll tax subsidies on minimum wage employment', Journal of Public Economics 82(1), 115-146.

Landais, C. (2007), 'Les hauts revenus en France (1998-2006): une explosion des inégalités', Working Paper, Paris School of Economics. Paris .

Lemieux, Thomas (2006), 'Increasing residual wage inequality: Composition effects, noisy data, or rising demand for skill?', American Economic Review 96(3), 461-498.

Machin, Stephen and John Van Reenen (2007), Changes in wage inequality. Centre for Economic Performance, London School of Economics and Political Science.

Magnac, Thierry and David Thesmar (2002), 'Analyse économique des politiques éducatives: l'augmentation de la scolarisation en France de 1982 à 1993', Annales d'économie et de statistique pp. 1-33.

Manacorda, Marco, Alan Manning and Jonathan Wadsworth (2012), 'The impact of immigration on the structure of wages: Theory and evidence from britain', Journal of the European Economic Association 10(1), 120-151.

Maurin, E. and S. McNally (2008), 'Vive la révolution! long-term educational returns of 1968 to the angry students', Journal of Labor Economics 26(1), 1-33.

Maurin, Éric (2007), La nouvelle question scolaire, Seuil.

Maurin, Éric (2009), La peur du déclassement: une sociologie des récessions, Seuil.

Neal, Derek and William R. Johnson (1996), 'The role of premarket factors in black-white wage differences', Journal of Political Economy 104(5), 869-95.

Olivetti, Claudia and Barbara Petrongolo (2008), 'Unequal pay or unequal employment? a crosscountry analysis of gender gaps', Journal of Labor Economics 26(4), 621-654.

Piketty, Thomas (2001), Les hauts revenus en France au 20éme siécle, Grasset. 
Verdugo, Gregory, Henri Fraisse and Guillaume Horny (2012), 'Évolution des Inégalites Salariales en France: le Rôle des Effets de Composition', Revue Économique 63(6), 10811112.

Vitry, Daniel (2010), Repères et références statistiques sur les enseignements la formation et la recherche, Technical Report RESR2009, Ministère de l'Éducation nationale et le ministére de l'Enseignement supérieur et de la Recherche, Paris.

Walker, Ian and Yu Zhu (2008), 'The college wage premium and the expansion of higher education in the uk', Scandinavian Journal of Economics 110(4), 695-709.

Wasmer, Etienne (2001a), Between-group competition in the labor market and the rising returns to skill: Us and france 1964-2000, IZA Discussion Papers 292, Institute for the Study of Labor (IZA).

Wasmer, Etienne (2001b), 'Measuring human capital in the labor market: The supply of experience in 8 oecd countries', European Economic Review 45(4-6), 861-874. 


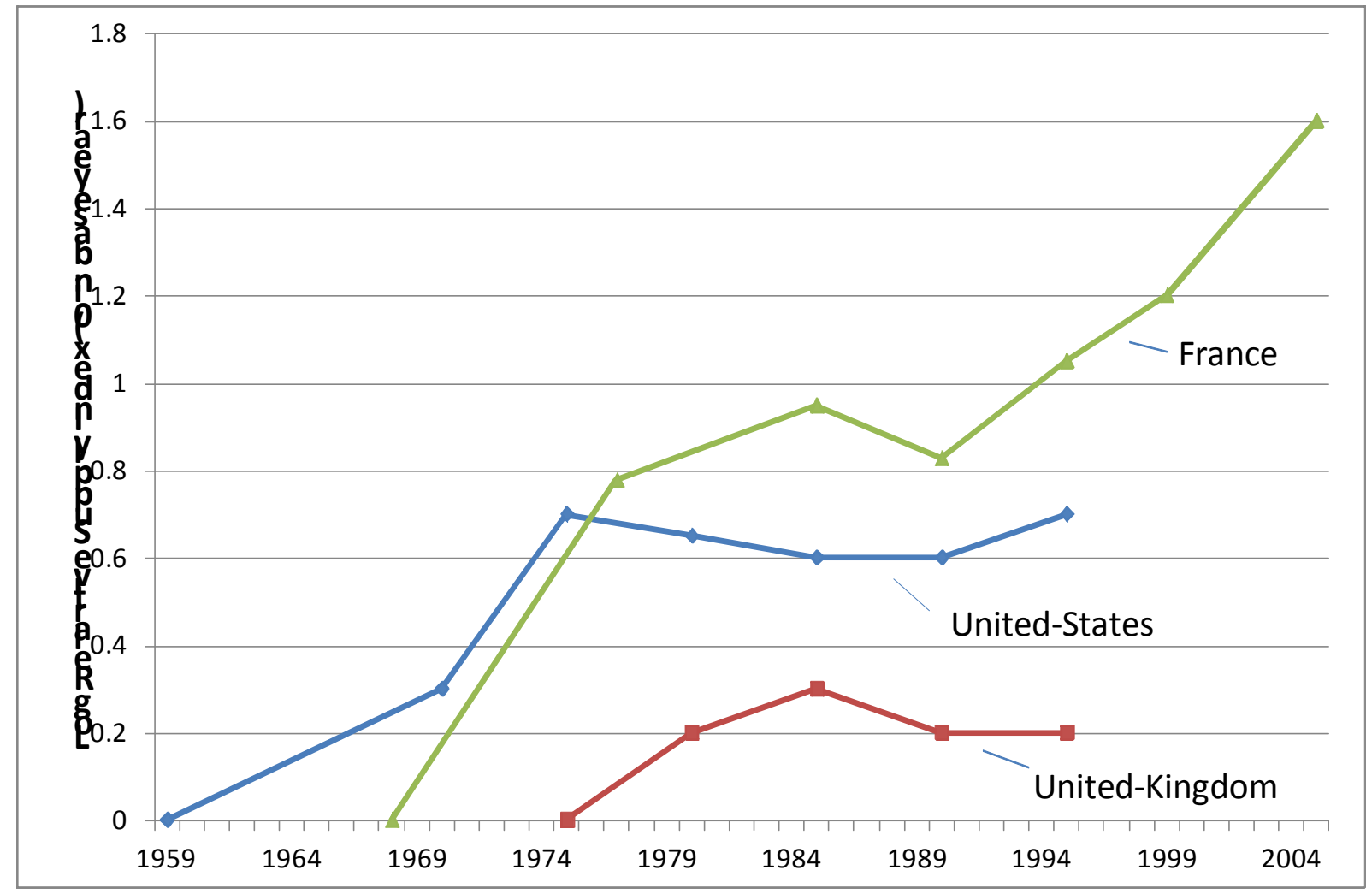

Figure 1: Relative Supply of Skilled Labor for 26-30 year Old Men:

France versus the US and the UK

Source: For the US and the UK, the figure represents the log of the number of university equivalent workers over high-school equivalents workers from Card and Lemieux (2001, p. 723). For France, the figure represents the log of the number of university or high-school graduates over the number of workers with education inferior to high-school. The figures are normalized to zero in the base year for each country. The sample is restricted to male workers aged 26-30 years old. 


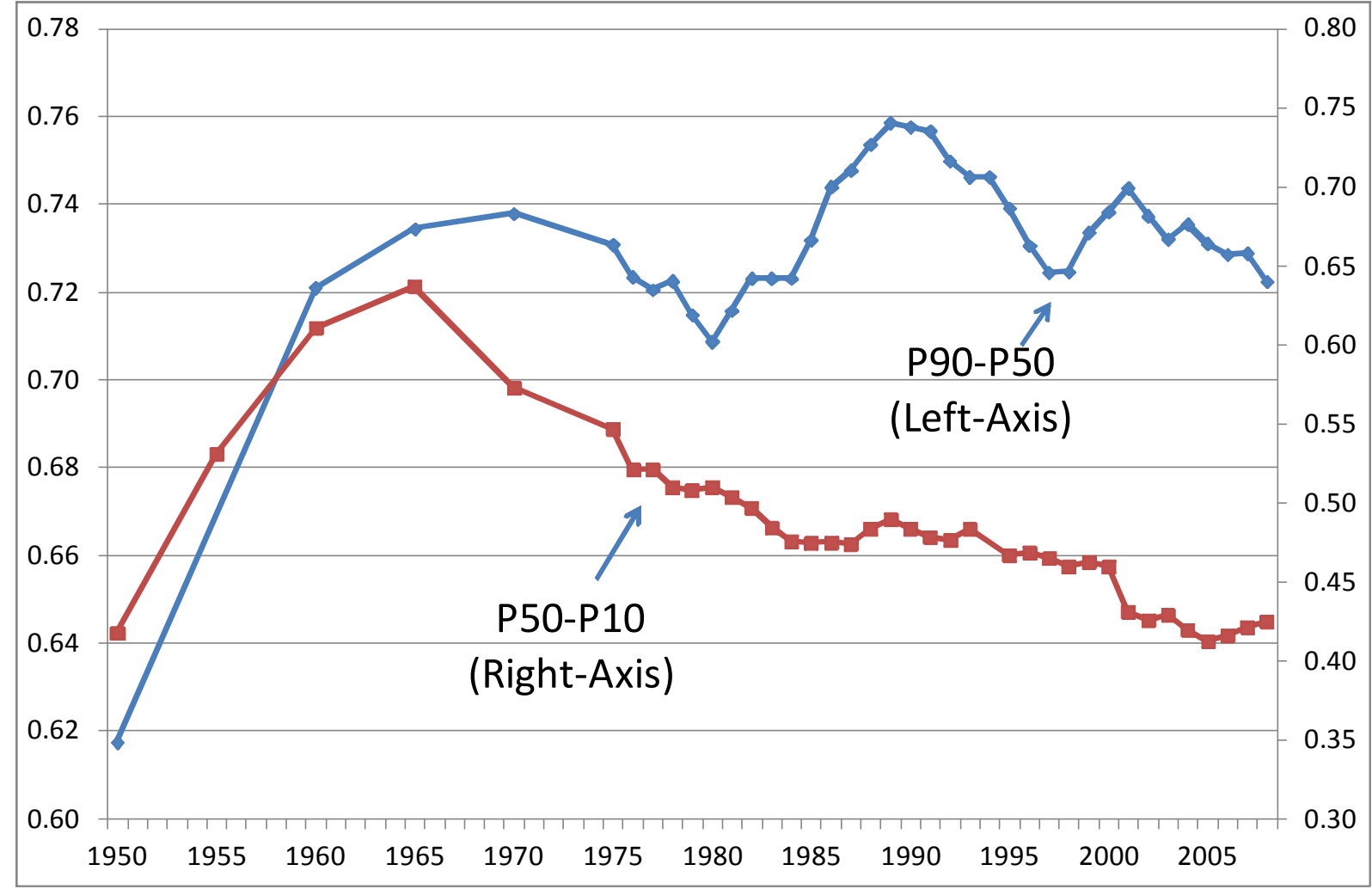

Figure 2: Upper and Lower Tail Wage Inequality, 1950-2008,

Source: DADS data 1950-2008 from published tabulations of the French Statistical Institute. The figure depicts the P90-P50 and the P50-P10 log wage gap of monthly wages for male working full-time full-year. 


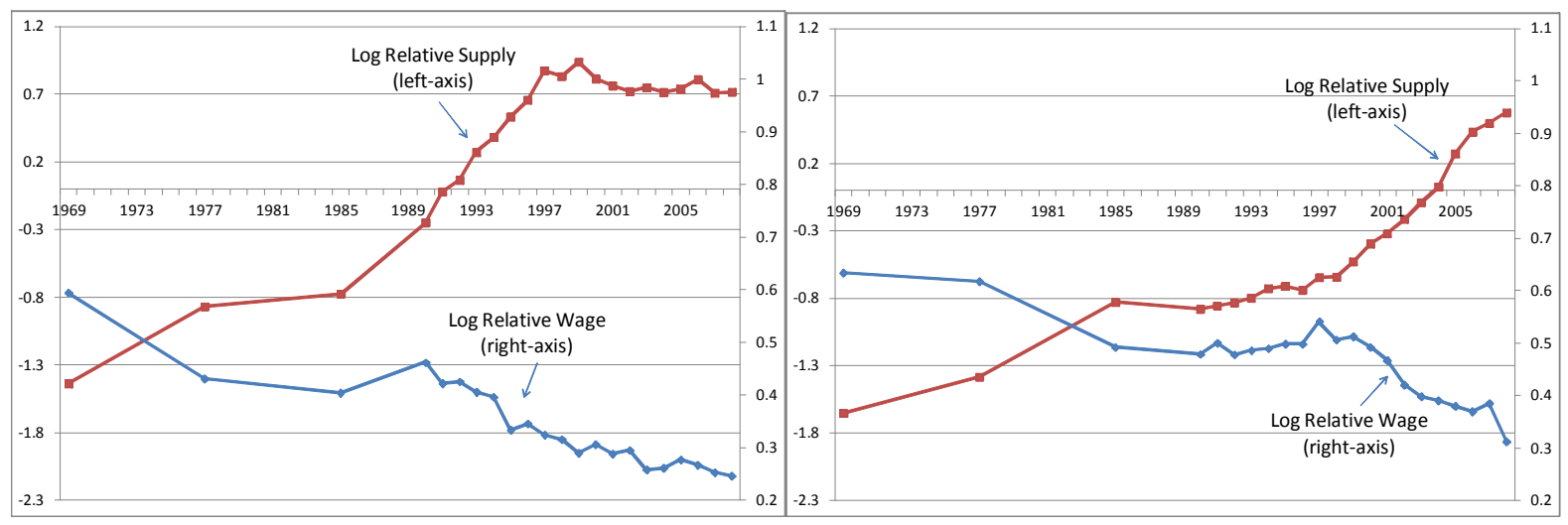

(a) 1 to 5 years of experience

(b) 11 to 15 years of experience

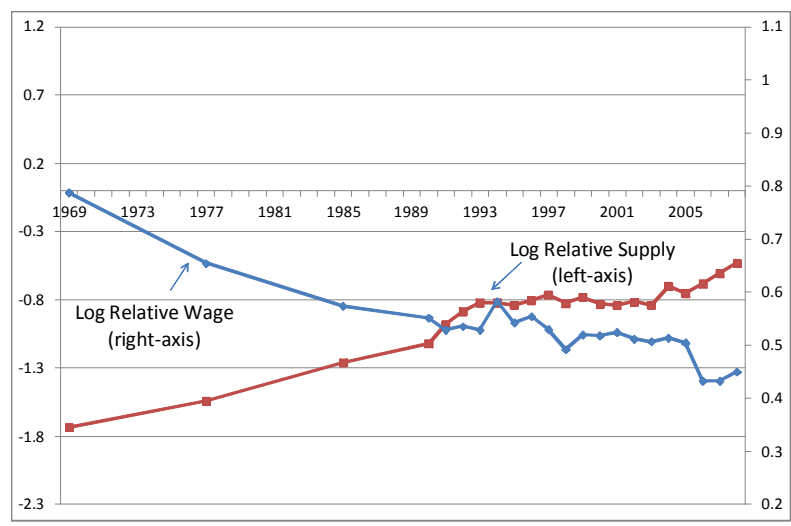

(c) 21 to 25 years of experience

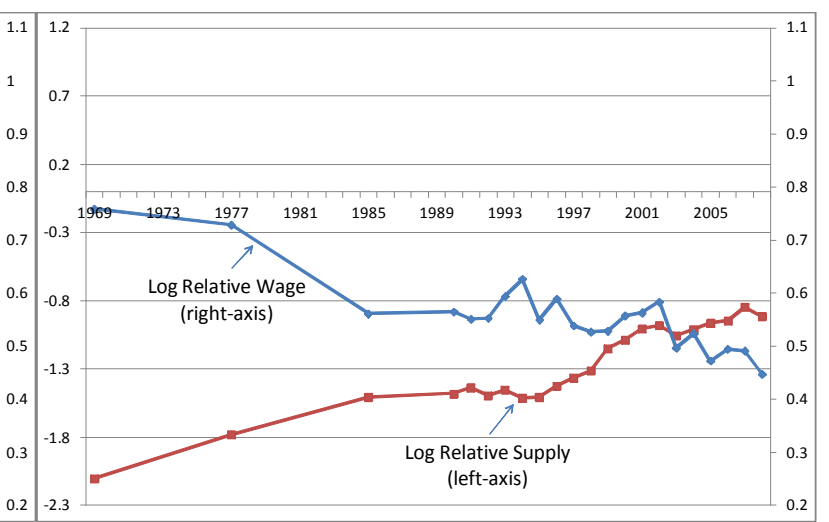

(d) 31 to 35 years of experience

Figure 3: Skill Premium and Relative Supply of Skilled Workers per Experience Groups

Source and Notes: FQP-LFS 1969-2008. Each graph represents the log of the relative monthly wages and the relative supply of skilled workers for the indicated potential experience groups. Skilled workers are those with a university or high-school degree while unskilled workers have a level of education inferior to high-school. The relative wage is the difference between average log monthly wages in the skilled and unskilled group. The relative supply is the logarithm of the ratio of the number of individuals in the two skill groups. 


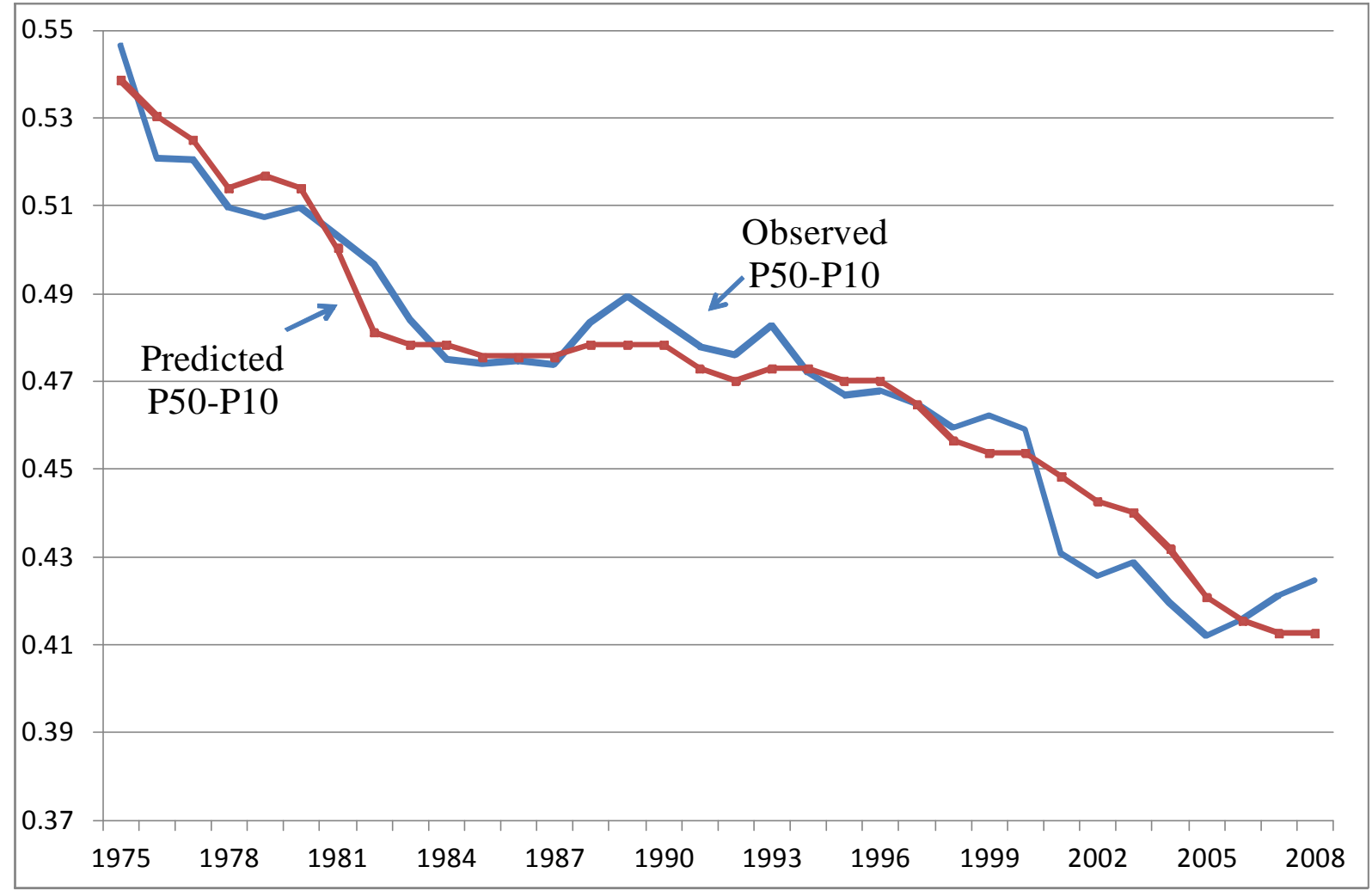

Figure 4: Observed and Predicted P50P10 log wage gap

Note: The figure depicts the P50P10 log wage gap from DADS. The figure also includes the predicted value of the P50P10 from a bivariate model using the minimum wage as a predictor (Table 7, column 4). 
Table 1: Population and Labour Markets Characteristics, Men

\begin{tabular}{|c|c|c|c|c|c|c|}
\hline \multicolumn{7}{|c|}{ A. Labour Market } \\
\hline & 1962 & 1970 & 1980 & 1990 & 2000 & 2008 \\
\hline & \multicolumn{6}{|c|}{ Labour Force Participation Rate by Age } \\
\hline less 25 & 62.7 & 69.7 & 66.7 & 52 & 47.4 & 55.3 \\
\hline $25-55$ & 95.1 & 96.9 & 96.4 & 95.3 & 94.1 & 94.4 \\
\hline \multirow[t]{2}{*}{ more than 55} & 74.5 & 74.1 & 65.4 & 41.5 & 36.2 & 41.9 \\
\hline & \multicolumn{6}{|c|}{ Employment Rate by Age } \\
\hline less 25 & 62.3 & 67.2 & 58.5 & 43.4 & 38.7 & 44.8 \\
\hline $25-55$ & 94.6 & 95.9 & 89.4 & 89.9 & 87.1 & 88.8 \\
\hline more than 55 & 73.9 & 71.9 & 57.4 & 39 & 33.5 & 39.4 \\
\hline $\begin{array}{l}\text { Av. GDP Growth in } \\
\text { Past } 5 \text { years }\end{array}$ & $7 \%$ & 5.6 & 3.4 & 3.1 & 2.7 & 2 \\
\hline \multirow[t]{2}{*}{ Log (P10/ Min Wage) } & 0.15 & 0.06 & 0.10 & 0.10 & 0.03 & 0.10 \\
\hline & \multicolumn{6}{|c|}{ B. Education (age more than 25) } \\
\hline Primary School & 81.3 & 65.4 & 50.8 & 46.9 & 34.4 & 28.9 \\
\hline Secondary & 10.7 & 22.9 & 31.5 & 28.7 & 32.1 & 29.5 \\
\hline High School & 4.2 & 4.8 & 5.8 & 9.7 & 11.5 & 16 \\
\hline \multirow[t]{2}{*}{ University } & 3.8 & 6.9 & 11.9 & 14.8 & 21.9 & 25.5 \\
\hline & \multicolumn{6}{|c|}{$\begin{array}{c}\text { Annual Increase in Percentage Points } \\
\text { of the Share of Education Groups in the Population }\end{array}$} \\
\hline$\Delta \geq$ High-School & na & 0.39 & 0.50 & 0.29 & 0.71 & 0.45 \\
\hline
\end{tabular}

Source and Notes: Census of Population 1962; LFS for other years. Tabulations from the author including men aged between 18 and 64 years old. The ratio (Minimum Wage/P50) is estimated with DADS data. Wage data from published tabulations of DADS from the French Statistical Institute. 
Table 2: Wage Inequality in France (Men), FQP-LFS and DADS

\begin{tabular}{|c|c|c|c|c|c|c|}
\hline & $\begin{array}{l}\text { DADS } \\
\text { Data }\end{array}$ & \multicolumn{2}{|c|}{ Monthly Wages } & \multicolumn{2}{|c|}{ Hourly Wages } & $\begin{array}{c}\text { Constant } \\
\text { Composition }\end{array}$ \\
\hline & $(1)$ & (2) & (3) & (4) & (5) & (6) \\
\hline & & $\begin{array}{c}\text { Age } \\
16-64\end{array}$ & $\begin{array}{c}\text { Age } \\
25-55\end{array}$ & Observed & $\begin{array}{c}\text { Imputed } \\
\text { unemployed }\end{array}$ & $\begin{array}{c}1985 \text { Xs, } \\
\text { DFL Method }\end{array}$ \\
\hline & \multicolumn{6}{|c|}{ P90-P50 } \\
\hline $1969 *$ & 0.74 & 0.76 & 0.75 & & & 0.90 \\
\hline 1976 & 0.72 & 0.66 & 0.65 & & & 0.71 \\
\hline 1984 & 0.72 & 0.65 & 0.62 & & & 0.65 \\
\hline 1990 & 0.76 & 0.66 & 0.65 & 0.66 & 0.68 & 0.67 \\
\hline 1995 & 0.74 & 0.64 & 0.62 & 0.62 & 0.64 & 0.62 \\
\hline 2000 & 0.74 & 0.66 & 0.63 & 0.62 & 0.63 & 0.62 \\
\hline 2005 & 0.73 & 0.66 & 0.62 & 0.56 & 0.57 & 0.59 \\
\hline \multirow[t]{2}{*}{2008} & 0.72 & 0.61 & 0.58 & 0.52 & 0.53 & 0.54 \\
\hline & \multicolumn{6}{|c|}{ P50-P10 } \\
\hline $1969 *$ & 0.57 & 0.46 & 0.46 & & & 0.48 \\
\hline 1976 & 0.52 & 0.46 & 0.45 & & & 0.48 \\
\hline 1984 & 0.48 & 0.43 & 0.42 & & & 0.43 \\
\hline 1990 & 0.48 & 0.40 & 0.41 & 0.42 & 0.52 & 0.39 \\
\hline 1995 & 0.47 & 0.42 & 0.40 & 0.44 & 0.54 & 0.39 \\
\hline 2000 & 0.46 & 0.41 & 0.40 & 0.42 & 0.50 & 0.35 \\
\hline 2005 & 0.41 & 0.35 & 0.36 & 0.36 & 0.48 & 0.31 \\
\hline 2008 & 0.42 & 0.35 & 0.37 & 0.36 & 0.42 & 0.31 \\
\hline $\begin{array}{c}\text { Wage } \\
\text { concept }\end{array}$ & Annual & Monthly & Monthly & Hourly & Hourly & Monthly \\
\hline $\begin{array}{c}\text { Sample } \\
\text { Restriction }\end{array}$ & $\begin{array}{l}\text { Full time, } \\
\text { Full year }\end{array}$ & Full time & Full time & $\begin{array}{c}\text { No } \\
\text { restriction }\end{array}$ & $\begin{array}{c}\text { No } \\
\text { restriction }\end{array}$ & Full time \\
\hline Age & All workers & $16-64$ & $25-55$ & $25-55$ & $25-55$ & $16-64$ \\
\hline $\begin{array}{c}\text { Data } \\
\text { source: }\end{array}$ & DADS & FQP-LFS & FQP-LFS & LFS & LFS & FQP-LFS \\
\hline
\end{tabular}

Sources: Column 1: DADS data from published tabulations of the French Statistical Institute. Other Columns: Data from FQP 1970, 1977, 1985 and LFS after 1990. Tabulations from the author. * refer to wages from 1969 for FQP and from 1970 for DADS. Wages from full-time full-year workers in FQP and full-time workers in the reference month for LFS.

Notes: The table reports the 90-50 and the 50-10 log wage gap for males in France.

Columns 2 and 3: Monthly wages for male full-time workers in both sources age 16-65, full-year in FQP.

Columns 3 to 5 restrict the sample to workers aged 25-55.

Columns 4 and 5 use hourly wages and include part time workers.

Column 5 includes unemployed workers in the sample with imputed wages. See text for details on imputation procedure.

Column 6: Counterfactual log wage gap estimated with FQP-LFS and the DFL reweighting technique by keeping the distribution of education and experience constant across 36 groups using the 1985 distribution. See text for details. 
Table 3: Wage Inequality in France, US, UK and Germany (Men)

\begin{tabular}{|c|c|c|c|c|c|c|}
\hline & \multicolumn{2}{|c|}{ France } & \multirow[t]{2}{*}{ US } & \multirow[t]{2}{*}{ UK } & \multirow[t]{2}{*}{ Germany } & \multirow{2}{*}{$\begin{array}{c}\text { France } \\
\text { FQP-LFS }\end{array}$} \\
\hline & DADS & FQP-LFS & & & & \\
\hline & \multicolumn{4}{|c|}{ P90-P50 } & \multicolumn{2}{|c|}{ P85-P50 } \\
\hline 1964 & 0.73 & & 0.51 & 0.59 & & \\
\hline $1970 *$ & 0.74 & 0.76 & 0.55 & 0.54 & & 0.57 \\
\hline 1976 & 0.72 & 0.66 & 0.55 & 0.52 & & 0.49 \\
\hline 1984 & 0.72 & 0.65 & 0.61 & 0.63 & 0.37 & 0.47 \\
\hline 1990 & 0.76 & 0.66 & 0.66 & 0.65 & 0.39 & 0.49 \\
\hline 2000 & 0.74 & 0.66 & 0.76 & 0.71 & 0.44 & 0.51 \\
\hline \multirow[t]{2}{*}{2005} & 0.73 & 0.66 & 0.86 & 0.73 & & 0.51 \\
\hline & \multicolumn{4}{|c|}{ P50-P10 } & \multicolumn{2}{|c|}{ P50-15 } \\
\hline 1964 & 0.64 & & 0.61 & 0.39 & & \\
\hline $1970 *$ & 0.57 & 0.46 & 0.58 & 0.39 & & 0.36 \\
\hline 1976 & 0.52 & 0.46 & 0.69 & 0.39 & & 0.38 \\
\hline 1984 & 0.48 & 0.43 & 0.84 & 0.47 & 0.26 & 0.35 \\
\hline 1990 & 0.48 & 0.40 & 0.80 & 0.58 & 0.27 & 0.34 \\
\hline 2000 & 0.46 & 0.41 & 0.80 & 0.62 & 0.32 & 0.33 \\
\hline 2005 & 0.41 & 0.35 & 0.83 & 0.61 & & 0.30 \\
\hline
\end{tabular}

Sources and notes:

Column 1 and 2: See table 2. * for France, wages from 1970 for DADS and 1969 for FQP. Column 3: Figures for the US from Autor et al. (2008, p.304) using CPS March Weekly with male full-time, full-year workers.

Column 4: Figures for the UK from Gosling et al. (1994, p.65) with Family Expenditure Surveys from 1966 to 1990, age 23-59 years. From 2000 and 2005, New Earning Survey from Machin and Van Reenen (2007, p.14).

Column 5: For Germany, Dustmann et al. (2009, online appendix, table A4, A5, p22.) with $I A B S$, male full-time aged 21-60; the sample excludes self-employed and civil servants. In columns 5 and 6, the 85-50 and the 50-15 log wage gap are reported. 
Table 4: Within and between wage inequality in France (Men)

\begin{tabular}{|c|c|c|c|c|c|c|c|}
\hline & \multicolumn{3}{|c|}{ Skill Premium } & \multicolumn{4}{|c|}{ Residual Inequality } \\
\hline & \multirow[b]{2}{*}{ (1) } & \multirow[b]{2}{*}{ (2) } & \multirow[b]{2}{*}{ (3) } & \multicolumn{2}{|c|}{ Regression Based } & \multicolumn{2}{|c|}{ Av. Within group gap } \\
\hline & & & & $(4)$ & $(5)$ & (6) & (7) \\
\hline & Observed & Median & $\begin{array}{l}\text { Median } \\
\text { Imputed }\end{array}$ & P90-P50 & P50-P10 & P90-P50 & P50-P10 \\
\hline $1969 *$ & 0.73 & & & 0.50 & 0.41 & 0.52 & 0.40 \\
\hline 1976 & 0.62 & & & 0.44 & 0.40 & 0.46 & 0.40 \\
\hline 1984 & 0.53 & & & 0.43 & 0.38 & 0.45 & 0.37 \\
\hline 1990 & 0.52 & 0.56 & 0.55 & 0.45 & 0.34 & 0.46 & 0.34 \\
\hline 1995 & 0.50 & 0.51 & 0.51 & 0.43 & 0.34 & 0.44 & 0.35 \\
\hline 2000 & 0.49 & 0.48 & 0.48 & 0.43 & 0.33 & 0.44 & 0.35 \\
\hline 2005 & 0.43 & 0.37 & 0.36 & 0.46 & 0.33 & 0.46 & 0.33 \\
\hline 2008 & 0.37 & 0.32 & 0.31 & 0.44 & 0.33 & 0.45 & 0.34 \\
\hline $\begin{array}{l}\text { Wage } \\
\text { concept }\end{array}$ & Monthly & Hourly & Hourly & Monthly & Monthly & Monthly & Monthly \\
\hline
\end{tabular}

Source: Author's calculation from FQP-LFS.

In Column 1, the skill premium is a fixed-weighted average of the difference between average wage of skilled and unskilled workers estimated separately using 8 potential experience groups. The distribution of experience in 1990 is used to compute the weights. The skilled group includes high-school and university graduates. The unskilled group includes individuals with less than high-school education.

Column 2 uses a fixed weighted average of the difference between median hourly wages of skills and unskilled workers with experience 5-35.

Column 3 uses a sample including imputed wages for unemployed workers.

Columns 4 and 5 show the residual log wage gap estimated with FQP-LFS using the residuals from a regression of log wages on 32 groups of education and potential experience, estimated separately each year.

Columns 6 and 7 use the weighted average of within group wage dispersion using 32 groups of education and potential experience. 
Table 5: Regression Models for the Skill Wage Gap across Age or Experience groups

\begin{tabular}{|l|c|c|c|c|c|c|}
\hline \multicolumn{6}{|c|}{ Dependent Variable: Skill Premium Wage Gap, by Cohort and Year (Men) } \\
\hline & $(1)$ & $(2)$ & $(3)$ & $(4)$ & $(5)$ & $(6)$ \\
\hline Period & $1990-2008$ & $1990-2008$ & $1990-2008$ & $1991-2008$ & $1991-2008$ & $1969-2008$ \\
\hline Group Specific & $-0.082^{* * *}$ & $-0.082^{* * *}$ & $-0.076^{* * *}$ & $-0.110^{* * *}$ & $-0.096^{* * * *}$ & $-0.074 * * *$ \\
\hline Relative Supply & $(0.010)$ & $(0.015)$ & $(0.013)$ & $(0.019)$ & $(0.020)$ & $(0.014)$ \\
\hline $\mathrm{N}$ & 152 & 152 & 133 & 143 & 143 & 64 \\
\hline R2 & 0.93 & 0.95 & 0.92 & 0.93 & 0.92 & 0.95 \\
\hline Year Fixed Effects & Yes & Yes & Yes & Yes & Yes & Yes \\
\hline $\begin{array}{l}\text { Min Wage x Group } \\
\text { Interaction }\end{array}$ & No & Yes & Yes & Yes & Yes & Yes \\
\hline Group Definition & Exp. & Exp. & Age & Exp. & Exp. & Exp. \\
\hline Sample & LFS & LFS & LFS & DADS & DADS & FQP-LFS \\
\hline Wage Concept & Monthly & Monthly & Monthly & Full-year & Daily & Monthly \\
\hline
\end{tabular}

Source: Wage data from annual LFS surveys 1990-2008 and FQP 1970, 1977, 1985; annual DADS-EDP in column 3 and 4.

Notes: Each column presents a regression of the log skill premium for workers with the same level of potential experience or age on the group specific relative supply of skills. Relative supply indexes are calculated using FQP and LFS in all models.

All columns use potential experience groups except column 3 which uses age groups.

Columns 1, 2 and 3 use annual data from 1990 to 2008 to estimate the model (1991 for column 3 and 4). Column 6 and 5 use data from year 1969, 1976, 1984, 1990, 1995, 2000, 2005 and 2008. Each model includes fixed effects for each group of experience or age.

Models in columns 2 to 6 include controls for the interaction between the real minimum wage level and group fixed effects.

Robust standard errors are reported in parenthesis.

$*$ Statistically significant at the .10 level; **at the .05 level; ***at the .01 level. 
Table 6: Robustness of the Results to Alternative Measures of the Wage Gap and Alternative Sample Definition

\begin{tabular}{|c|c|c|c|c|c|}
\hline \multicolumn{6}{|c|}{ Dependent Variable: Skill Premium Wage Gap, by Cohort and Year (Men), LFS data } \\
\hline & $(1)$ & $(2)$ & $(3)$ & $(4)$ & $(5)$ \\
\hline Group Specific & $-0.097 * * *$ & $-0.078 * * *$ & $-0.079 * * *$ & $-0.094 * * *$ & $-0.127 * * *$ \\
\hline Relative Supply & $(0.018)$ & $(0.012)$ & $(0.012)$ & $(0.015)$ & $(0.035)$ \\
\hline $\mathrm{N}$ & 152 & 114 & 114 & 40 & 40 \\
\hline R2 & 0.90 & 0.95 & 0.95 & 0.94 & 0.94 \\
\hline Wage concept & $\begin{array}{l}\text { Only Univ. } \\
\text { Grad. In } \\
\text { skill group }\end{array}$ & $\begin{array}{l}\text { Median } \\
\text { hourly }\end{array}$ & $\begin{array}{l}\text { Median } \\
\text { hourly }\end{array}$ & $\begin{array}{l}\text { Average } \\
\text { monthly }\end{array}$ & $\begin{array}{l}\text { Average } \\
\text { Monthly }\end{array}$ \\
\hline Method & OLS & OLS & OLS & OLS & 2 SLS \\
\hline Imputation? & No & No & Yes & No & No \\
\hline Instrument & & & & & $\begin{array}{l}\text { Policy } \\
\text { Change }\end{array}$ \\
\hline Year and Group FE & Yes & Yes & Yes & Yes & Yes \\
\hline Cells Definition & Exp 1-40 & Exp 5-35 & Exp 5-35 & Exp 1-40 & Exp 1-40 \\
\hline First Stage F & & & & & 15.6 \\
\hline Period & 1990-2008 & 1990-2008 & $\begin{array}{l}1990- \\
2008\end{array}$ & $\begin{array}{c}1990,95, \\
2000,05,08\end{array}$ & $\begin{array}{c}1990,95, \\
2000,05,08\end{array}$ \\
\hline
\end{tabular}

Source and Notes: Each column presents a regression of the skilled log wage gap for workers with the same level of potential experience or age on group specific relative supply of skills. The dependent variable is calculated by using wage data from FQP-LFS.

In Column 1, the skill premium is calculated by allocating only university graduates in the skilled group.

Column 2 uses the median hourly wage of employed workers within cells instead of the average.

Column 3 uses the median wage calculated with a sample including unemployed workers with an imputed wage. See text for details on imputation procedure.

Column 4 and 5 only uses data from years 1990, 1995, 2000, 2005 and 2008.

Column 5 estimates the model using 2SLS with a dummy interacted with a trend related to the educational policy change as an instrument.

Robust standard errors are reported in parenthesis.

*Statistically significant at the .10 level; **at the .05 level; ***at the .01 level. 
Table 7: Regression models for the overall skill premium and wage dispersion

\begin{tabular}{|l|c|c|c|c|}
\hline \multicolumn{5}{|c|}{ A. LFS Data 1990-2008 } \\
\hline Dependent Variable: & \multicolumn{4}{|c|}{ Aggregate Skill Premium } \\
\hline & $(1)$ & $(2)$ & $(3)$ & $(4)$ \\
\hline Relative Supply & -0.280 & -0.237 & -0.197 & \\
\hline Index & $(0.213)$ & $(0.203)$ & $(0.217)$ & \\
\hline Time & 0.005 & 0.002 & 0.001 & \\
\hline & $(0.010)$ & $(0.009)$ & $(0.010)$ & \\
\hline Log Real Minimum Wage & & 0.181 & 0.162 & $-0.601^{* * *}$ \\
\hline & & $(0.106)$ & $(0.112)$ & $(0.189)$ \\
\hline Unemployment rate & & & 0.212 & \\
\hline & & & $(0.341)$ & \\
\hline N & 19 & 19 & 19 & 19 \\
\hline R2 & 0.91 & 0.92 & 0.93 & 0.37 \\
\hline
\end{tabular}

B. DADS Data: $1975-2008$

\begin{tabular}{|c|c|c|c|c|}
\hline Dependent Variable: & \multicolumn{4}{|c|}{ P50-P10 log wage gap } \\
\hline Relative Supply & -0.014 & 0.001 & -0.004 & \\
\hline Index & $(0.012)$ & $(0.009)$ & $(0.010)$ & \\
\hline \multirow[t]{2}{*}{ Time } & $-0.002 * * *$ & -0.001 & -0.001 & \\
\hline & $(0.001)$ & $(0.001)$ & $(0.001)$ & \\
\hline \multirow[t]{2}{*}{ Log Real Minimum Wage } & & $-0.217 * * *$ & $-0.215^{* * *}$ & $-0.274 * * *$ \\
\hline & & $(0.042)$ & $(0.042)$ & $(0.012)$ \\
\hline \multirow[t]{2}{*}{ Unemployment rate } & & & 0.126 & \\
\hline & & & $(0.101)$ & \\
\hline $\mathrm{N}$ & 34 & 34 & 34 & 34 \\
\hline $\mathrm{R} 2$ & 0.90 & 0.95 & 0.95 & 0.94 \\
\hline Dependent Variable: & \multicolumn{4}{|c|}{ P90-P50 log wage gap } \\
\hline Relative Supply & 0.000 & 0.002 & -0.013 & \\
\hline Index & $(0.014)$ & $(0.015)$ & $(0.015)$ & \\
\hline \multirow[t]{2}{*}{ Time } & 0.000 & 0.000 & 0.001 & \\
\hline & $(0.001)$ & $(0.001)$ & $(0.001)$ & \\
\hline \multirow[t]{2}{*}{ Log Real Minimum Wage } & & -0.021 & -0.015 & 0.023 \\
\hline & & $(0.067)$ & $(0.062)$ & $(0.019)$ \\
\hline \multirow[t]{2}{*}{ Unemployment rate } & & & $0.396 * *$ & \\
\hline & & & $(0.148)$ & \\
\hline $\mathrm{N}$ & 34 & 34 & 34 & 34 \\
\hline $\mathrm{R} 2$ & 0.06 & 0.06 & 0.24 & 0.05 \\
\hline
\end{tabular}

Source and Notes: The relative supply index is estimated by using an elasticity $\sigma_{x}$ of 12 and estimated values of $\alpha_{i}$ using Eq. 1, calculated using annual LFS 1975-2008. Panel A: Each column presents OLS regressions results of the log ratio of the fixed-weighted university/less than high-school wage differential on the indicated variables. Panel B and C: Each column 
presents an OLS regression of either the P50-P10 or the P90-P50 log wage gap on the indicated variables. Annual P90-P50 and P50-P10 log wage gap for male full-time full-year from DADS tabulation published by the INSEE. Robust standard errors are reported in parenthesis.

$*$ Statistically significant at the .10 level; **at the .05 level; ***at the .01 level. 
Table 8: Simulations of the wage impact of increases in experience specific relative supply

\begin{tabular}{|c|c|c|c|c|c|c|c|}
\hline & $(1)$ & $(2)$ & $(3)$ & $(4)$ & $(5)$ & $(6)$ & $(7)$ \\
\hline & \multicolumn{2}{|c|}{$\begin{array}{c}\text { Observed } \\
\text { Wage Gap }\end{array}$} & \multirow{2}{*}{$\begin{array}{c}\text { Total } \\
\text { change }\end{array}$} & \multicolumn{2}{|c|}{$\begin{array}{c}\text { Predicted change } \\
\text { with } \sigma_{x}=9\end{array}$} & \multicolumn{2}{|c|}{$\begin{array}{c}\text { Predicted change } \\
\text { with } \sigma_{x}=13\end{array}$} \\
& 1969 & 2008 & & $\begin{array}{c}\text { Effect of } \\
\text { supply }\end{array}$ & Residual & $\begin{array}{c}\text { Effect of } \\
\text { supply }\end{array}$ & Residual \\
\hline
\end{tabular}

A. Effect on the Skill Premium

\begin{tabular}{|c|c|c|c|c|c|c|c|}
\hline \multicolumn{8}{|c|}{ Experience group } \\
\hline $1-5$ & 0.59 & 0.25 & -0.35 & -0.19 & -0.16 & -0.13 & -0.22 \\
\hline $6-10$ & 0.65 & 0.24 & -0.41 & -0.23 & -0.18 & -0.16 & -0.25 \\
\hline $11-15$ & 0.63 & 0.31 & -0.32 & -0.25 & -0.07 & -0.17 & -0.15 \\
\hline $16-20$ & 0.80 & 0.41 & -0.39 & -0.19 & -0.20 & -0.13 & -0.25 \\
\hline $21-25$ & 0.79 & 0.45 & -0.34 & -0.13 & -0.20 & -0.09 & -0.25 \\
\hline $26-30$ & 0.83 & 0.43 & -0.40 & -0.13 & -0.28 & -0.09 & -0.32 \\
\hline $31-35$ & 0.76 & 0.45 & -0.31 & -0.13 & -0.18 & -0.09 & -0.22 \\
\hline $36-40$ & 0.82 & 0.51 & -0.31 & -0.12 & -0.19 & -0.08 & -0.22 \\
\hline $\begin{array}{l}\text { Overall skill } \\
\text { Premium }\end{array}$ & 0.73 & 0.37 & -0.36 & -0.18 & -0.18 & -0.12 & -0.23 \\
\hline \multicolumn{8}{|c|}{ B. Effect on Wage Distribution } \\
\hline P90P50 & 0.76 & 0.61 & -0.15 & -0.07 & -0.08 & -0.05 & -0.10 \\
\hline P50P10 & 0.46 & 0.35 & -0.11 & -0.02 & -0.09 & -0.01 & -0.10 \\
\hline
\end{tabular}

Source and Notes: Panel A decomposes changes in experience group specific skill premium in a part explained by changes in education supply and a residual part. Column 1 and 2 show, respectively, the skill premium in 1969 and 2008. Column 3 reports the observed change between these two years. Column 4 shows a counterfactual change of the skill premium over the period predicted by the change in group specific supply, using an elasticity of substitution of 9 . Column 4 shows the unexplained part of the change which is by definition the difference between column 3 and 4. Column 6 and 7 provide a similar decomposition but use instead an elasticity of 13 to predict the change in the skill premium. Panel B shows the corresponding effects of changes in experience group education supply on upper and lower tail wage inequality. The counterfactual effects on wage inequality are obtained by adjusting the wages of skilled workers in 1968 within each experience group such that the counterfactual skill premium predicted for 2008 correspond to the one predicted by the change in group specific supply. The rest of the decomposition is similar. 